\title{
Abundance and fate of thallium and its stable isotopes in the environment
}

\author{
Zdzisław M. Migaszewski $($ D $\cdot$ Agnieszka Gałuszka $(\mathbb{D}$
}

Received: 4 October 2020/ Accepted: 30 December 2020/Published online: 12 February 2021

(C) The Author(s) 2021

\begin{abstract}
This overview presents the updated physicochemical characteristics of thallium and its stable isotopes $\left({ }^{205} \mathrm{Tl} /{ }^{203} \mathrm{Tl}\right)$ in the context of their occurrence and fate in abiotic and biotic systems. This also deals with the thallium behavior in geochemical interactions in and between different environmental compartments and describes its natural (geogenic) and industrial sources. The particular emphasis is placed on some extreme environments, including acid mine drainage areas where oxidation processes of $\mathrm{Tl}$ bearing pyrite and other sulfides lead to very high concentrations of this metal in reactive acidic waters. Many geochemical studies have also employed stable thallium isotopes to reconstruct redox conditions in different environmental systems, to fingerprint relative pollution source strengths and to evaluate mobility of this element and its geochemical interactions in the mineral-water and soil-plant systems. This is the reason why this overview also highlights the growing potential of stable $\mathrm{Tl}$ isotopes in solving different geologic and environmental issues.
\end{abstract}

Z. M. Migaszewski $(\bowtie) \cdot$ A. Gałuszka Institute of Chemistry, Jan Kochanowski University, 7 Uniwersytecka St., 25-406 Kielce, Poland

e-mail: zmig@ujk.edu.pl

\section{Graphic abstract}

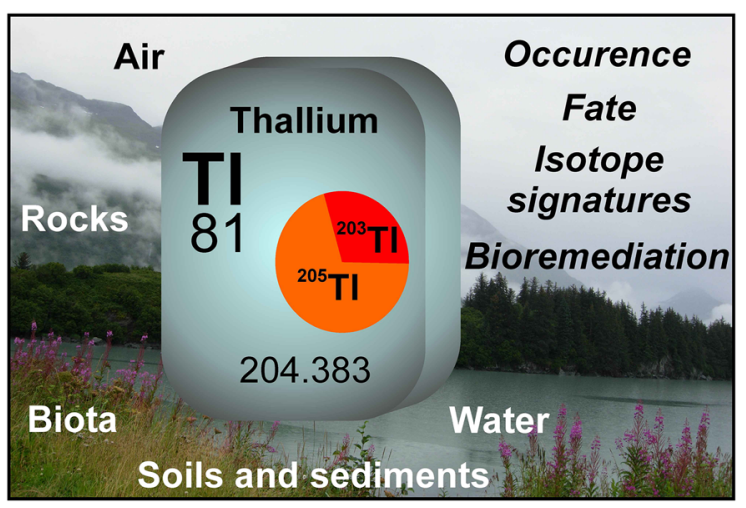

Keywords Thallium - Geochemical interactions · Environmental compartments · Acid mine drainage . Stable $\mathrm{Tl}$ isotopes

\section{Introduction}

Until the beginning of the 20th century, thallium had widely been used in medicine for treating ringworms on scalps, tuberculosis, malaria, venereal diseases, and even longer until the sixties of the 20th century, Tl salts had been employed as rodenticides and insecticides (Nriagu 1998; Kazantzis 2000). Nowadays, thallium has found applications in many areas of industry, such as manufacturing of: antifriction alloys 
(with $\mathrm{Sn}, \mathrm{Sb}$, and $\mathrm{Pb}$ ), low-freezing alloys (with $\mathrm{Hg}$ ), low-melting special glasses with an admixture of $\mathrm{S}, \mathrm{Se}$ and As, photocells, high-temperature superconductor materials, semiconductor material for selenium rectifiers, low-temperature thermometers (Nriagu 1998; Kazantzis 2000; Karbowska 2016; Belzile and Chen 2017). Thallium compounds are also utilized in cardiovascular imaging to detect heart diseases, and in various cancer detections (USGS 2019). Furthermore, thallium is also used as a probe to emulate the biological functions of alkali earth metal ions (Nriagu 1998; Peter and Viraraghavan 2005).

The geochemical fate of thallium in many environmental compartments has been hindered due to low concentrations which are typically in the range of $\mathrm{ng} /$ $\mathrm{L}-\mu \mathrm{g} / \mathrm{L}$ or $n g / \mathrm{kg}-\mu \mathrm{g} / \mathrm{kg}$. An increased number of thallium determinations in geologic, environmental, biological and industrial materials has been possible due to rapid developments in mass spectrometry techniques employing inductively coupled-atomic/ optical emission spectrometry (ICP-AES/ICP-OES), single collector sector-field or quadrupole inductively coupled-mass spectrometry (SFICP-MS, QICP-MS) (e.g., Xiao et al. 2004a b; Krachler et al. 2008; Li et al. 2009; Kellerhals et al. 2010; Casiot et al. 2011; Bačeva et al. 2014; Vaněk et al. 2015; Karbowska 2016; Caritat and Reimann 2017; Di Candia et al. 2020), and multi collector-inductively coupled plasma-mass spectrometry (MC-ICP-MS), which has also been used to measure ${ }^{205} \mathrm{Tl} /{ }^{203} \mathrm{Tl}$ ratios (e.g., Nielsen et al. 2004; 2017; Vaněk et al. 2020). Another very sensitive analytical technique of thallium determination is flow-injection differential-pulse anodic stripping voltammetry (FI-DP-ASV), enabling a determination of $\mathrm{Tl}$ in waters at a concentration of $\mathrm{pg} / \mathrm{L}$ (Jakubowska et al. 2008).

Thallium (Tl) is of great concern due to its geoavailability, mobility, dispersivity, bioaccessibility, bioavailability, and toxicity to plant and animal species. Many thallium studies have been centered on natural and man-induced pollution sources in the context of their implications for the environment and humans (Zhang et al. 1998; DelValls et al. 1999; Cheam 2001; Xiao et al. 2012, 2004a, b; Murciego et al. 2010; Casiot et al. 2011; Bačeva et al. 2014; Tatsi and Turner 2014; Gomez-Gonzalez et al. 2015; Vaněk et al. 2015, 2016; Campanella et al. 2016, 2017; Wojtkowiak et al. 2016; Biagioni et al. 2017; Grösslova et al. 2018; Perotti et al. 2018; Cruz-
Hernández et al. 2018; D’Orazio et al. 2020). It should be mentioned that different physicochemical, environmental, toxicological and technological issues of this toxic metal have been reviewed in several papers (e.g., Kazantzis 2000; Heim et al. 2002; Twidwell and Williams-Beam 2002; Peter and Viraraghavan 2005; Karbowska 2016; Caritat and Reimann 2017; Belzile and Chen 2017; Xu et al. 2019; Liu et al. 2019a; Zhang and Rickaby 2020).

The principal objective of this review is to summarize and update the literature data about the physicochemical characteristics, occurrence, and behavior of thallium in geochemical interactions. The authors also briefly describe the significance of natural (geogenic) sources of this metal with a special emphasis on acid mine drainage (AMD) areas where the highest concentrations of thallium have been found in surface- and groundwaters (e.g., Zitko 1975; Xiao et al. 2003; Alpers et al. 2003; Casiot et al. 2011; Petrini et al. 2016; Campanella et al. 2016; Perotti et al. 2018; Liu et al. 2019a). These areas are occupied by tailings piles, mineral settling tanks, strongly acidic seeps and derelict lands posing a real hazard to various abiotic and biotic systems, including human beings. Recently, a variety of geochemical studies have also employed stable thallium isotopes to reconstruct redox conditions in different aquatic systems, to fingerprint relative pollution source strengths and to evaluate mobility of this element and its geochemical interactions in the mineral-water and soil-plant systems (e.g., Rehkämper and Nielsen 2004; Enghag 2004; Nielsen et al. 2004, 2006, 2009, 2011, 2017; Baker et al. 2009; Vaněk et al. 2015, 2016, 2020; Grösslova et al. 2018). This is the reason why this paper also gives an overview on applications of ${ }^{205} \mathrm{Tl} /{ }^{203} \mathrm{Tl}$ ratios in solving various geologic and environmental issues.

\section{Physical and chemical characteristics of thallium}

Thallium belongs to the group 13 of the Periodic Table of the Elements (Fig. 1). This is a gray, very soft and malleable element with an atomic number of 81. A relative atomic mass of 204.383 amu with high density $\left(11.71 \mathrm{~g} / \mathrm{cm}^{3}\right.$ at $\left.20^{\circ} \mathrm{C}\right)$ classifies $\mathrm{Tl}$ as a "heavy" metal (Reimann and Caritat 1998, Kabata-Pendias and Szteke 2015). Its name comes from the Greek word "thallos" $(\theta \alpha \lambda \lambda \mathrm{s})$ that stands for a young twig or a budding shoot after the green line in its flame spectrum 


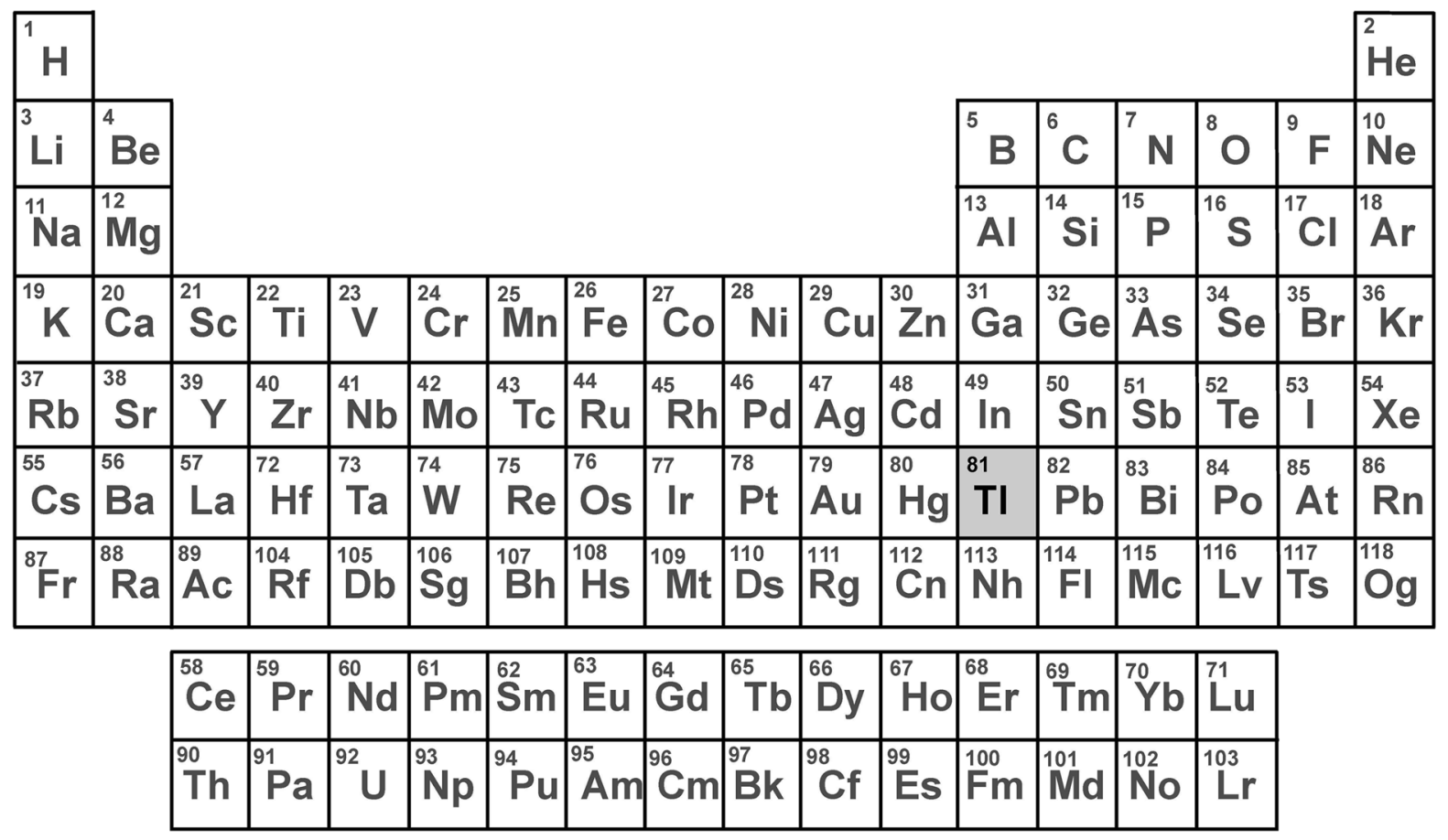

Fig. 1 Position of thallium in the periodic table of the elements

(Kazantzis 2000). This element was discovered by the English chemist Sir William Crookes in 1861 whereas metallic thallium was obtained by the French scientist Claude-Auguste Lamy in 1862.

According to Goldschmidt's geochemical classification (1954), thallium is a chalcophilic element, like neighboring $\mathrm{Hg}$ and $\mathrm{Pb}$, concentrating mostly in sulfides. However, there is extensive geologic work that has been done showing that even though $\mathrm{Tl}$ was originally characterized as chalcophile, in practice this is not necessarily true. Thallium predominantly behaves as a lithophilic element in a wide variety of geologic environments (substituting for $\mathrm{K}^{+}, \mathrm{Rb}^{+}$and $\mathrm{Cs}^{+}$in the crystal structures of different rock-forming minerals) and very rarely displays chalcophile behavior, only under unique conditions when lithophile behavior is not possible (Hettmann et al. 2014; Greaney et al. 2017; Rader et al. 2018).

$\mathrm{Tl}$ atomic radius is $208 \mathrm{pm}$ whereas ionic radii are in the range of: $164-184 \mathrm{pm}\left(\mathrm{Tl}^{+}\right)$and $89-112 \mathrm{pm}$ $\left(\mathrm{Tl}^{3+}\right)$ (Reimann and Caritat 1998). Thallium occurs in two oxidation states as: monovalent (thallous, $\mathrm{Tl}^{+}$) as in $\mathrm{Tl}_{2} \mathrm{O}$ and $\mathrm{Tl}_{2} \mathrm{SO}_{4}$, or as $\mathrm{Tl}_{2} \mathrm{~S}$ in strongly reducing conditions, sporadically trivalent under oxidizing and alkaline conditions (thallic, $\mathrm{Tl}^{3+}$ ) as in $\mathrm{Tl}_{2} \mathrm{O}_{3}, \mathrm{Tl}(\mathrm{OH})_{3}$ and $\mathrm{TlCl}_{3}$ (Lin and Nriagu 1999). Generally, thermodynamically more stable $\mathrm{Tl}^{+}$is the predominant chemical species in nearly all environmental systems. In marine environments, $\mathrm{Tl}^{+}$is adsorbed and oxidized by negatively charged $\mathrm{Mn}$ oxides (and to a lesser extent by neutrally charged $\mathrm{Fe}$ oxides), resulting in oxidation of $\mathrm{Tl}^{+}$to $\mathrm{Tl}^{3+}$ on the surface during adsorption. This is what ultimately results in the extreme isotopic fractionation of $\mathrm{Tl}$ by $\mathrm{Mn}(+\mathrm{Fe})$

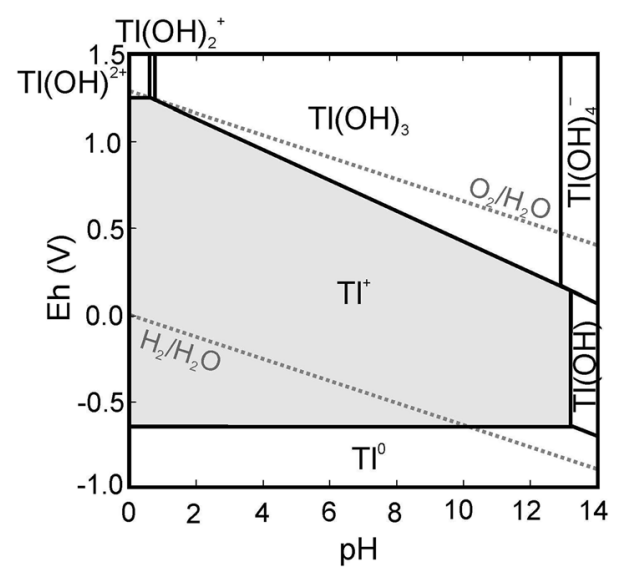

Fig. 2 Eh-pH diagram of the Tl-H-O systems (compiled from Davies et al. 2016; Xu et al. 2019) 
oxides, which leads to very positive isotope compositions. The Eh-pH diagram showing the strong predominance of $\mathrm{Tl}^{+}$is presented in Fig. 2.

Scavenging of thallium does not occur at a $\mathrm{pH}$ of $<3$, but easily takes place at a $\mathrm{pH}$ of $\sim 6.5$ (Karlsson et al. 2006). The oxidation state of thallium plays a significant role in $\mathrm{Tl}$ sorption (Karlsson et al. 2006). According to Rehkämper and Nielsen (2004), 1 to 5\% of total $\mathrm{Tl}$ occurs in seawater as $\mathrm{Tl}^{3+}$. In the $\mathrm{pH}$ range of 2 to 12 and high redox potential, $\mathrm{Tl}^{3+}$ forms insoluble $\mathrm{Tl}(\mathrm{OH})_{3}$. A reversible light-dependent oxidation of $\mathrm{Tl}^{+}$to $\mathrm{Tl}^{3+}$ coupled with photoreduction of $\mathrm{Fe}^{3+}$ to $\mathrm{Fe}^{2+}$ was observed by Karlsson et al. (2006). According to these authors, the redox state of thallium in freshwater systems is controlled by the iron cycle.

Pure thallium occurs is scarce in nature because the surface of metallic $\mathrm{Tl}$ is readily oxidized. However, occurrences of native $\mathrm{Tl}$ were reported from Momotombo volcanic sublimates (Quisefit et al. 1989). Thallium forms many inorganic compounds, including hydrides, fluorides, chlorides, bromides, iodides, mixed halides, such as thallium(III) fluoride dichloride $\left(\mathrm{TlFCl}_{2} \cdot 3 \mathrm{H}_{2} \mathrm{O}\right)$, oxyhalides, oxides, hydroxides, chalcogenides, salts with oxoanions etc. (Aldridge 2011; Jones and Stasch 2011). Many organothallium compounds are known, with the bisubstituted derivatives $\left(\mathrm{R}_{2} \mathrm{TlX}\right)$ being the most stable (Haiduc and Zuckerman 2011).

\section{Occurrence and abundances of thallium in the environment}

Even though global production of thallium is relatively low amounting to approximately $15 \mathrm{t}$ per year, the annual release of $\mathrm{Tl}$ from different pollution sources into the environment is high ranging from 2000 to $5000 \mathrm{t}$ (Kazantzis 2000). There are two groups of contamination sources: (i) the geologic (geogenic) ones including Tl-bearing near-surface metal ore deposits and exposed or shallow sub-surface mineralized rock formations, and (ii) the anthropogenic ones including atmospheric emissions, solid wastes and wastewaters derived mostly from sulfide ore and coal mining and processing (sometimes classified as geoanthropogenic sources), metal sulfide ore smelting, industrial and domestic bituminous (hard) coal and lignite combustion, waste incineration, petroleum refining, and cement manufacturing (e.g., Schaub
1996; Nriagu 1998; Reimann and Caritat 1998; Leblanc et al. 1999; Kazantzis 2000; Alpers et al. 2003; Law and Turner 2011; Vaněk et al. 2016; Karbowska, 2016; Caritat and Reimann 2017; Belzile and Chen 2017; Liu et al. 2019a, b). The anthropogenic sources have the greatest potential and detrimental impact on various ecosystems and human beings. The geologic sources play a significant role in the areas of present and historic metal sulfide ore mining, mostly in southern China (Lanmuchang, Xiangquan), Republic of North Macedonia (Allchar), northern Italy (Tuscany), USA (Iron Mountain), Switzerland, France or southern Poland (BukownoOlkusz). The largest number of Tl-induced casualties, unparalleled throughout the world, was linked to the nearly 400-year mining history of the Lanmuchang $\mathrm{Hg}$-Tl-As mine district. Many people who populated this area have suffered from chronic thallium poisoning, including anorexia, alopecia, blindness and even fatalities. A total of 87 cases of thallium intoxication were reported in this mining district in 1960 alone (Zhang et al. 1998). Figure 3 depicts major geochemical processes governing environmental fate of thallium versus different natural and anthropogenic sources.

\subsection{Crustal abundance and mineralogy}

Thallium is ranked 60th in order of element abundances in the Earth's crust. This is a widely dispersed element in the Earth's crust at a mean concentration to be estimated approx. 0.71 to $1.0 \mathrm{mg} / \mathrm{kg}$ (Wedepohl 1995; Rickwood 1983), and a consensus range of 0.1 to $3.0 \mathrm{mg} / \mathrm{kg}$ (Fortescue 1992; Rickwood 1983). The content of this metal in igneous rocks varies from 0.05 to $1.8 \mathrm{mg} / \mathrm{kg}$ whereas in siliciclastic rocks from 0.4 to $2.0 \mathrm{mg} / \mathrm{kg}$ (Kabata-Pendias and Pendias 2011). Clayey fractions of sedimentary rocks show enrichments in $\mathrm{Tl}$ compared to their arenaceous counterparts. Organic-rich clayey shales contain up to $1000 \mathrm{mg} / \mathrm{kg}$ $\mathrm{Tl}$ (Kazantzis 2000). In contrast, limestones and dolomites are distinctly depleted in thallium ranging from 0.01 to $0.15 \mathrm{mg} / \mathrm{kg}$ (Kabata-Pendias and Pendias 2011). The high concentration of this element (up to $330 \mathrm{mg} / \mathrm{kg}$ ) was noted in exposed rocks (limestones, argillites) hosting the mercury-thallium-arsenic ore deposit in the Lanmuchang district of the southwestern Guizhou Province, southwestern part of China (Xiao et al. 2004b). Coals of this area contain up to $46 \mathrm{mg} / \mathrm{kg}$ 


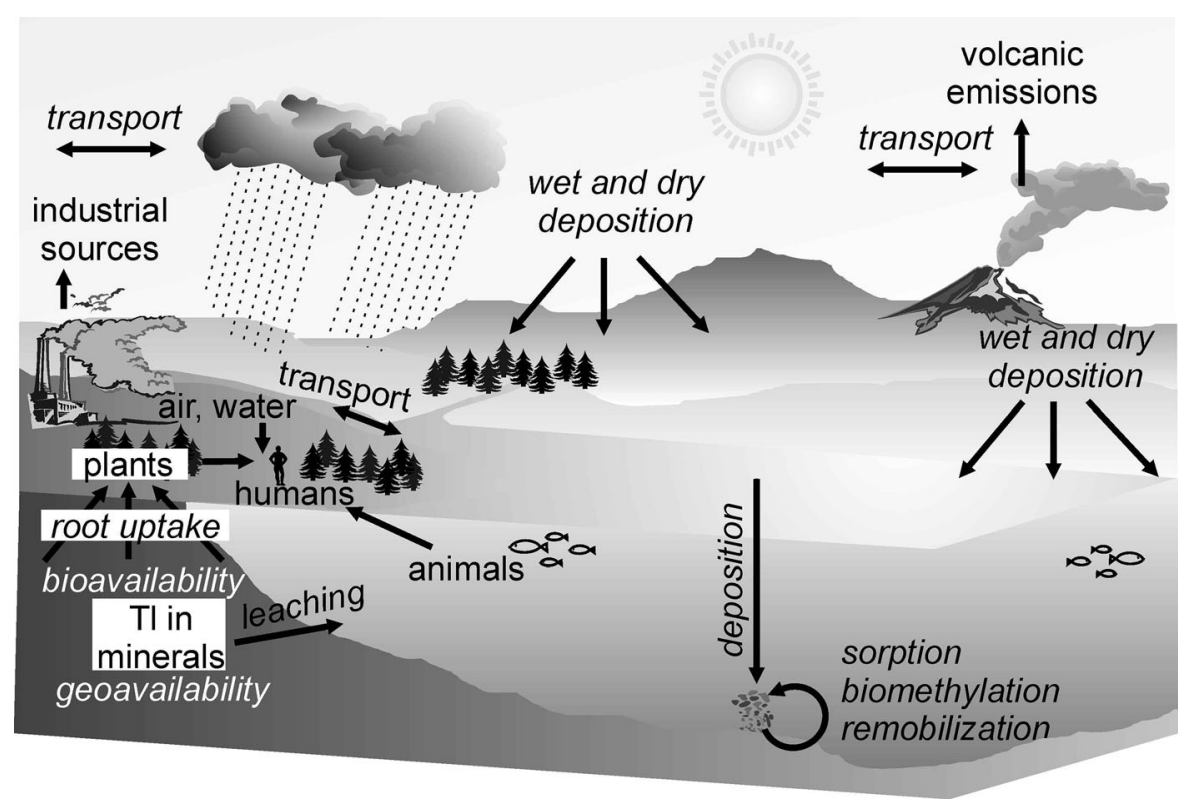

Fig. 3 Major geochemical processes governing environmental fate of thallium

$\mathrm{Tl}$, distinctly exceeding an average content of $3 \mathrm{mg} / \mathrm{kg}$ (Koljonen 1992).

As mentioned before, thallium has a large ionic radii and high coordination number, therefore it behaves as an incompatible element and is left for final stages of magmatic differentiation (e.g., more felsic rocks like granites or pegmatites). This is the reason why alkaline and acidic igneous rocks contain far more thallium than their mafic and ultramafic counterparts, for example $\mathrm{Tl}$ abundance in granite averages $0.75 \mathrm{mg} / \mathrm{kg}$ whereas in basalt approx. $0.1 \mathrm{mg} / \mathrm{kg}$ (Levinson 1980). Besides, $\mathrm{Tl}^{+}$radius is similar to $\mathrm{K}^{+}, \mathrm{Rb}^{+}$and $\mathrm{Cs}^{+}$radii thus favoring the occurrence of this element in more common potassium minerals, especially in K-feldspar, biotite, muscovite or sylvite, for example an IsoProbe MS-ICP-MS study of feldspar and mica samples showed $\mathrm{Tl}$ concentration over $20 \mathrm{mg} / \mathrm{kg}$ (Rader et al. 2018). Because $\mathrm{Tl}^{+}$and $\mathrm{Tl}^{3+}$ radii are far too large to substitute $\mathrm{Mg}^{2+}$ and $\mathrm{Fe}^{2+}$ in the lattice of olivine $(\mathrm{Mg}, \mathrm{Fe})_{2} \mathrm{SiO}_{4}$ and pyroxene $(\mathrm{Mg}, \mathrm{Fe})_{2} \mathrm{Si}_{2} \mathrm{O}_{6}$, which are the principal minerals of the Earth's mantle, hence these two mafic minerals are distinctly depleted in $\mathrm{Tl}$ in the range of $3-45 \mu \mathrm{g} / \mathrm{kg}$ (Jović 1993).

Additional geologic processes, such as hydrothermal alteration, may have a further impact on $\mathrm{Tl}$ distribution and behavior leading in some places to high concentrations of this metal. Of the thallium minerals, only lorandite $\mathrm{TlAsS}_{2}$ (Lanmuchang, China) and avicennite $\mathrm{Tl}_{2} \mathrm{O}_{3}$ (Luolong, Tibet) make up a few ore deposits (Liu et al. 2019a). The others, such as crookesite (Cu,Tl,Ag) $)_{2} \mathrm{Se}$, ellisite $\mathrm{Tl}_{3} \mathrm{AsS}_{3}$ and hutchinsonite $(\mathrm{Pb}, \mathrm{Tl})_{2} \mathrm{As}_{2} \mathrm{~S}_{9}$ are very scarce and are unmined. In the Krstov Dol antimony deposit of the Republic of North Macedonia, stibnite $\mathrm{Sb}_{2} \mathrm{~S}_{3}$ and berthierite $\mathrm{FeSb}_{2} \mathrm{~S}_{4}$ displayed relatively high thallium concentrations reaching $0.3 \%$ (Alderton et al. 2005). The largest number of Tl-rich sulfide deposits with proven $\mathrm{Tl}$ reserves of approx. 16,000 $\mathrm{t}$ occur in different provinces of China (cf. Liu et al. 2019a). Nonetheless, the most unique place throughout the world is the Sb-As-Tl sulfide ore deposit located in Allchar, near the border of the Republic of North Macedonia and Greece where lorandite and additionally 45 rare Tl-bearing minerals were found, including those typical only for this locality, namely jankovicite $\mathrm{Tl}_{5} \mathrm{Sb}_{9}(\mathrm{As}, \mathrm{Sb})_{4} \mathrm{~S}_{22}$, picotpaulite $\mathrm{TlFe}_{2} \mathrm{~S}_{3}$, rebulite $\mathrm{Tl}_{5 \text { - }}$ $\mathrm{Sb}_{5} \mathrm{As}_{8} \mathrm{~S}_{22}$ and simonite $\mathrm{TlHgAs}_{3} \mathrm{~S}_{6}$ (Boev et al. 2001-2002).

Thallium occurs more frequently as a trace element in metal sulfides reaching locally very high concentrations, for example, chalcopyrite $\mathrm{CuFeS}_{2}$, pyrite $\mathrm{FeS}_{2}$, sphalerite $\mathrm{ZnS}$ and galena $\mathrm{PbS}$ associated with epi- and telethermal $\left(<200{ }^{\circ} \mathrm{C}\right)$ metalogenesis contained up to $5 \%, 0.77 \% 1000 \mathrm{mg} / \mathrm{kg}$ and $20 \mathrm{mg} / \mathrm{kg} \mathrm{Tl}$, respectively (Viets et al. 1996; Twidwell and 
Williams-Beam 2002; Peter and Viraraghavan 2005; Xiong 2007; Zhou et al. 2008). In pyrite, for example, thallium may be incorporated into the crystal structure substituting for Fe or form tiny nano- and micro-sized inclusions of $\mathrm{Tl}$ mineral phases (Deditius and Reich 2016). It is interesting to note that an EMPA study showed substantial variability in $\mathrm{Tl}$ contents within sphalerite grains of the abandoned Santa Manolita mine in El Losar del Barco (Ávila, Spain) varying from 0.064 to $0.266 \mathrm{wt} \%$ (Murciego et al. 2010). In another LA-ICP-MS study of galena from the Bleikvassli $\mathrm{Fe}-\mathrm{Zn}-\mathrm{Pb}-\mathrm{Cu}$ sulfide ore deposit (Norway), concentrations of $\mathrm{Tl}$ ranged from 26.3 to $289 \mathrm{mg} / \mathrm{kg}$ (George 2013). The presence of variable Tl impurities within the sulfide crystal structure tends to decrease the mineral resistance to weathering (oxidation).

The highest concentrations of thallium (up to 3.5\%) were recorded in the Hg-Tl-As ores of the Lanmuchang area (Xiao et al. 2004b). Various metal oxyhydroxides and oxyhydroxysulfates, resulting from oxidation of primary sulfide minerals of this ore deposit contained up to $1100 \mathrm{mg} / \mathrm{kg}$ adsorbed and co-precipitated thallium whereas mine wastes revealed up to $2600 \mathrm{mg} / \mathrm{kg}$ Tl. Similarly, pyrite of the Silesian-Cracow $\mathrm{Zn}-\mathrm{Pb}-\mathrm{Fe}$ sulfide ore deposit (southern Poland) contained $800-1200 \mathrm{mg} / \mathrm{kg} \mathrm{Tl}$, but its post-flotation wastes were distinctly enriched in this metal reaching $5000 \mathrm{mg} / \mathrm{kg}$ (Karbowska 2016).

The exceptionally high contents of thallium (20.82 wt $\%$ as $\mathrm{Tl}_{2} \mathrm{O}$ ) were found in Mn-oxyhydroxides of a polymetallic mineralization zone at the Zalas quarry, near Cracow, southern Poland (Gołębiowska et al. 2017). High concentrations of this metal (range of 100 to $1000 \mathrm{mg} / \mathrm{kg}$ ) were also reported in Jurassic coals of Tadzhikistan (Smith and Carson 1977). In addition, deep-sea sediments, and Fe-Mn oxyhydroxide nodules, crusts or efflorescences are also abundant in $\mathrm{Tl}$ (discussed later).

\subsection{Soils}

Different studies have revealed that bedrock mineralogy and lithology generally contribute to thallium distribution patterns of soils, sediments, waters, and biota. Thallium is mobile in soils and its content generally varies from 0.01 to $0.5 \mathrm{mg} / \mathrm{kg}$ (KabataPendias and Pendias 2011). The Tl abundances in topsoil of Europe range from 0.05 to $24.0 \mathrm{mg} / \mathrm{kg}$ with a mean of $0.821 \mathrm{mg} / \mathrm{kg}(\mathrm{n}=840)$ and are close to those in subsoil varying from 0.01 to $21.3 \mathrm{mg} / \mathrm{kg}$ with a mean of $0.828 \mathrm{mg}(\mathrm{n}=783)$ (Salminen 2005). The similar average values were also reported in France (1.513 mg/kg; Tremel et al. 1997). These and other examples of $\mathrm{Tl}$ concentrations in soils are given in Table 1. More detailed data on thallium contents in soils, as well as in sediments, waters, and airborne particulates throughout the world were summarized by Belzile and Chen (2017).

Higher concentrations of $\mathrm{Tl}$ in soils, like in other abiotic systems, are scarce, for example, contaminated soils from the Lanmuchang $\mathrm{Hg}$ - Tl-As mineralized areas contained up to $124 \mathrm{mg} / \mathrm{kg} \mathrm{Tl}$ (Xiao et al. 2004b). For comparison, background soils of this area showed low concentrations of $\mathrm{Tl}$ in the range of $<0.2$ to $0.5 \mathrm{mg} / \mathrm{kg}$. Similarly, high levels of $\mathrm{Tl}$ in soils were reported in the areas of $\mathrm{Zn}-\mathrm{Pb}-\mathrm{Fe}$ sulfide ore mining and processing. For example, in the Silesian-Cracowian district, topsoil (0-0.2 m interval) contained up to $150 \mathrm{mg} / \mathrm{kg} \mathrm{Tl}$ (Jakubowska et al. 2007). However, the highest $\mathrm{Tl}$ concentrations worldwide (range of 0.11 to $20,000 \mathrm{mg} / \mathrm{kg}$ with a mean of $660 \mathrm{mg} / \mathrm{kg}, \mathrm{n}=134)$ were found in topsoil $(0-30 \mathrm{~cm})$ of the Allchar site linked to the hydrothermal As-Sb-Tl Crven Dol deposit located within Triassic altered carbonate rocks in the southern part of the Republic of North Macedonia (Bačeva et al. 2014). The mean of $660 \mathrm{mg} / \mathrm{kg}$ was $\sim 800$ times higher than that recorded for topsoil of Europe (Salminen 2005).

The results of a sequential extraction procedure performed on mining-affected soils in the Madrid Province (Spain) indicated that thallium derived from mine wastes did not undergo transformation into more labile and extractable fractions, and was mostly entrapped in a residual parent fraction, e.g., Tl-bearing quartz and aluminosilicate particles (Gomez-Gonzalez et al. 2015). $\mathrm{Tl}^{+}$ions are not significantly adsorbed onto Fe-oxyhydroxide colloidal phases, and do not undergo strong complexation by humic acids in soils, therefore these ions may move easily to pore water and subsequently to plants. Nonetheless, there is evidence that Mn-oxyhydroxides that form individual accumulations or coatings on different mineral grains, may also play a role in $\mathrm{Tl}$ retention (Jacobson et al. 2005). Thallium may also occur in soils as $\mathrm{Tl}$ secondary minerals - sulfates/oxyhydroxysulfates, for example jarosite of circumneutral soils near Buus in the Swiss Jura Mountains attained a maximum of $\sim 10,000 \mathrm{mg} /$ $\mathrm{kg} \mathrm{Tl}$ (Herrmann et al. 2018). As a result of enzyme 
Table $1 \mathrm{Tl}$ concentrations in selected sediments and soils $(\mathrm{mg} / \mathrm{kg})$

\begin{tabular}{|c|c|c|c|c|}
\hline Media & Locality & Range & Mean & References \\
\hline Marine sediments & World & $10-5700$ & - & Twidwell and Williams-Beam (2002) \\
\hline Stream sediments & Europe & $<0.002-7.90$ & 0.477 & Salminen (2005) \\
\hline Floodplain sediments & Europe & $<0.002-3.46$ & 0.451 & \\
\hline Estuarine sediments & Tamar, United Kingdom & $0.078-0.222$ & 0.080 & Anagboso et al. (2013) \\
\hline Marine sediments & Bohai Sea, China & & & Zhuang and Gao (2015) \\
\hline Summer & & $0.36-0.58$ & 0.42 & \\
\hline Autumn & & $0.30-0.56$ & 0.44 & \\
\hline River sediments & Laizhou Bay, China & & & \\
\hline Summer & & $0.34-0.76$ & 0.45 & \\
\hline Autumn & & $0.35-1.08$ & 0.47 & \\
\hline Post-tsunami sediments & Phuket Island, Thailand & $0.37-1.13$ & - & Łukaszewski et al. (2012) \\
\hline River sediments in mining area & As-Sb-Tl Allchar, Macedonia & $11-25$ & 17 & Bačeva et al. (2014) \\
\hline Upstream sediments & Allchar area, Macedonia & $0.62-0.87$ & 0.78 & \\
\hline Downstream sediments & Allchar area, Macedonia & $1.4-3.3$ & 2.3 & \\
\hline Pond sediments in unmined area & Tl Xiangquan, China & $0.39-1.29$ & 0.783 & Zhou et al. (2008) \\
\hline Loess & China, Moldavia, Tajikistan & $0.32-0.69$ & 0.52 & Nielsen et al. (2005) \\
\hline Topsoil & Europe & $0.05-24.0$ & 0.821 & Salminen (2005) \\
\hline Subsoil & Europe & $0.01-21.3$ & 0.828 & \\
\hline Natural soils & China & $0.282-1.17$ & 0.584 & Qi et al. (1992) \\
\hline Surface soils & Across Norway & $0.02-1.40$ & 0.184 & Nygård et al. (2012) \\
\hline Forest soils & Czech Republic & $0.56-1.65$ & - & Vaněk et al. (2009) \\
\hline Grassland soils & Czech Republic & $1.11-2.06$ & - & \\
\hline Arable soils & France & $0.04-55$ & 1.513 & Tremel et al. (1997) \\
\hline Topsoil & EuroRegion Neisse & $<25->100$ & 0.5 & Heim et al. (2002) \\
\hline Urbisols & Alcalá, Spain & $0.03-0.25$ & 0.12 & Peña-Fernández et al. (2014) \\
\hline Technosols & & $0.04-0.28$ & 0.12 & \\
\hline Soils in mining area & $\mathrm{Zn}-\mathrm{Pb}-\mathrm{Fe}$ Olkusz area, Poland & $1-139$ & - & Cabała and Teper (2007) \\
\hline Soils in unmined area & Tl Xiangquan, China & $0.39-6.87$ & 0.80 & Zhou et al. (2008) \\
\hline Tl-ore & & $149.8-2210$ & 1133.2 & \\
\hline Pyrite & & $132.2-7117$ & 2701.2 & \\
\hline Mineralized soils & As-Sb-Tl Allchar, Macedonia & $0.11-20,000$ & 660 & Bačeva et al. (2014) \\
\hline Soils in mining area & Hg-Tl-As Lanmuchang, China & $1.5-124$ & 63 & Xiao et al. (2004b) \\
\hline Sulfide ores & Hg-Tl-As Lanmuchang, China & $100-35,000$ & 4400 & \\
\hline Secondary minerals & Hg-Tl-As Lanmuchang, China & $25-1100$ & 89 & \\
\hline Mine wastes & Hg-Tl-As Lanmuchang, China & $32-2600$ & 136 & \\
\hline
\end{tabular}

leaching or a $\mathrm{pH}$ decrease (under reducing conditions), thallium may be released from these mineral scavengers.

The experimental study performed by Vaněk et al. (2012) showed that low molecular-weight organic acid solutions (including citric, oxalic, and acetic acids) were 2.7 -fold more effective in removing lithogenic thallium than the water alone. The maximum values were obtained for oxalate after 0.5 -h leaching. This batch experiment also revealed that illite and $\mathrm{Mn}^{3+}$ / $\mathrm{Mn}^{4+}$ oxides, and to a lesser extent orthoclase and muscovite, controlled $\mathrm{Tl}$ solubility by effective adsorption of this metal on their surfaces. Adsorption 
of thallium onto illite was also confirmed by Wick et al. (2018).

\subsection{Sediments}

Thallium concentrations in lake sediments are in the range of 2.1 to $23.1 \mathrm{mg} / \mathrm{kg}$ with a mean of $13.1 \mathrm{mg} / \mathrm{kg}$ (Mathis and Kevern 1975) whereas in marine sediments from 0.08 to $5 \mathrm{mg} / \mathrm{kg}$ (Matthews and Riley 1970). The concentrations of $\mathrm{Tl}$ in stream sediments of Europe range from $<0.002$ to $7.90 \mathrm{mg} / \mathrm{kg}$, with a mean of $0.477 \mathrm{mg} / \mathrm{kg}$ (Salminen et al. 2005). A study conducted by Zhuang and Gao (2015) in the Laizhou Bay and the Bohai Sea (China) indicated seasonal variations in $\mathrm{Tl}$ contents (Table 1). For comparison, contaminated river sediments within a zone of hydrothermally altered rocks of the As-Sb-Tl Crven Dol deposit contained somewhat increased levels of $\mathrm{Tl}$ varying from 0.62 to $0.87 \mathrm{mg} / \mathrm{kg}$ with a mean of $0.78 \mathrm{mg} / \mathrm{kg}$ (Bačeva et al. 2014). The other examples of $\mathrm{Tl}$ occurrences in sediments are presented in Table 1. More detailed data on $\mathrm{Tl}$ concentrations in sediments of different sites throughout the world were reported by Belzile and Chen (2017). In the high oxidizing and alkaline environments, this element undergoes oxidation from $\mathrm{Tl}^{+}$to $\mathrm{Tl}^{3+}$, and subsequently adsorption and complexation by predominant clay minerals, primarily by illite and vermiculite, and to a lesser extent by montmorillonite and kaolinite (Mathews and Riley 1970; Jacobson et al. 2005; Kersten et al. 2014).

Because sediments are closely linked to aquatic biota, so it is important to evaluate their potential ecological risk by determining concentrations of toxic elements. Based on the ecological risk indices (ERI) derived from the study of Swedish lakes, Håkanson (1980) divided sediments into five classes:
(i) low risk $(\leq 40)$;
(ii) moderate risk ( $>40$ to $\leq 80)$;
(iii) considerable risk $(>80$ to $\leq 160)$;
(iv) high risk ( $>160$ to $\leq 320)$;
(v) very high risk $(>320)$.

One of the examples was an assessment of the $\mathrm{Tl}$ potential ecological risk of sediments in the Zaozhuang Section of the Beijing-Hangzhou Grand Canal, China. Thallium concentrations were in the range of 0.46 to $0.70 \mathrm{mg} / \mathrm{kg}$ with a mean of $0.61 \mathrm{mg} / \mathrm{kg}$ whereas the ERI varied from 9.41 to 14.38 with an average of 12.52 , which corresponded to a very low risk (Liu et al. 2018).

The study of the Tamar estuary sediments and water column in southwestern England showed a lack of geochemical interactions (adsorption-desorption) between these two media (Anagboso et al. 2013). Low concentrations of $\mathrm{Tl}(\sim 80 \mu \mathrm{g} / \mathrm{kg})$ were observed across the tidal estuary sediments, with an excursion into the most landward site $(\sim 220 \mu \mathrm{g} / \mathrm{kg})$, which pointed to inputs from mineralized areas, or short-term diagenetic processes in sediments.

Bioturbation/bioirrigation may release $\mathrm{Tl}$ from contaminated sediments to the water column, thus jeopardizing aquatic biota as evidenced by the batch experiments performed on riverine organism groups: Tubificid, Chironomid larvae, and Loach. During the first 9 days, bioturbation enhanced the release of $\mathrm{Tl}$ to the water column and finally ceased after 28 days of the experiment. Along with an increased $\mathrm{pH}, \mathrm{Fe}$ - and Mn-oxyhydroxides formed subsequently scavenging $\mathrm{Tl}$ from water (He et al. 2015). Biomethylation and oxidation of $\mathrm{Tl}^{+}$to $\left(\mathrm{CH}_{3}\right)_{2} \mathrm{Tl}^{+}$, activated by anaerobic bacteria, were noted in lake and marine sediments (Huber and Kirchmann 1978; Schedlbauer and Heumann 2000). Due to similar standard redox potential $\left(\mathrm{E}_{0}\right)$ of thallium $(1.25 \mathrm{~V})$ and manganese $(1.23 \mathrm{~V})$, which are higher than that of iron $(0.77 \mathrm{~V})$, thallium tends to concentrate in oceanic ferromanganese oxyhydroxide nodules, crusts or efflorescences (Gao et al. 2007). The Fe-Mn oceanic crusts contain up to $100 \mathrm{mg} / \mathrm{kg}$ Tl (Wedepohl 1972; Twidwell and Williams-Beam 2002). However, in the reducing environments, thallium undergoes desorption being released from manganese oxyhydroxides into the water column.

\subsection{Aqueous systems}

Surface waters play an important role in transporting and distributing of thallium among different abiotic and biotic systems. $\mathrm{Tl}^{+}$ion is also a predominant chemical species in terrestrial aqueous systems undergoing oxidation to $\mathrm{Tl}^{3+}\left(\mathrm{Tl}(\mathrm{OH})_{3}\right)$ at moderate $\mathrm{pH}$ and Eh conditions (range of 0.0-1.2 mV). Concentrations of $\mathrm{Tl}$ in some selected aqueous systems are presented in Table 2. Except for acid mine drainage waters (discussed later), most lake and river waters show low levels of thallium in the 5-10 $\mathrm{ng} / \mathrm{L}$ range (Peter and Viraraghavan 2005). Concentrations of $\mathrm{Tl}$ in stream 
Table 2 Concentrations of thallium in selected surface, underground and mine waters

\begin{tabular}{|c|c|c|c|c|}
\hline Medium & Locality & Range & Mean & References \\
\hline Open ocean seawater (ng/L) & & $10-20$ & - & $\begin{array}{l}\text { Owens et al. (2017) and Böning } \\
\text { et al. (2018) }\end{array}$ \\
\hline Streams and rivers $(\mathrm{ng} / \mathrm{L})$ & Europe & $<2-7900$ & 477 & Salminen (2005) \\
\hline Rivers (ng/L) & Across the World & $1.31-16.7$ & - & Nielsen et al. (2005) \\
\hline Amazon & Estuary & 16.4 & - & \\
\hline Danube & Central Europe & 16.0 & - & \\
\hline Nile & Egypt & 3.13 & - & \\
\hline Rhine & Germany & $3.61-6.71$ & - & \\
\hline Volga & Russia & 1.60 & - & \\
\hline $\begin{array}{l}\text { Beijing-Hangzhou Grand } \\
\text { Canal }(\mu \mathrm{g} / \mathrm{L})\end{array}$ & China & $0.46-0.70$ & 0.61 & Liu et al. (2018) \\
\hline Streams and rivers $(\mu \mathrm{g} / \mathrm{L})$ & Oslo area, Norway & $<0.01-0.02$ & 0.01 & Reimann et al. (2009) \\
\hline Lake waters (ng/L) & Great Lakes & $0.09-48.1$ & 10.6 & Cheam (2001) \\
\hline Tap waters (ng/L) & Across Italy & $<0.5-291$ & 5.5 & Dinelli et al. (2012) \\
\hline \multirow[t]{3}{*}{ Snow (ng/kg) } & Devon 1999, Canada & $0.12-3.40$ & 0.24 & Krachler et al. (2008) \\
\hline & Devon 2000, Canada & $0.03-2.81$ & 0.45 & \\
\hline & Devon 2004, Canada & $0.35-1.12$ & 0.50 & \\
\hline Snow and ice (ng/kg) & Arctic & $0.0-8.4$ & 0.8 & Cheam (2001) \\
\hline Natural waters $(\mu \mathrm{g} / \mathrm{L})$ & $\begin{array}{l}\text { Unmined Tl-ore deposit Xiangquan, } \\
\text { China }\end{array}$ & $<0.05-0.65$ & - & Zhou et al. (2008) \\
\hline Surface waters $(\mu \mathrm{g} / \mathrm{L})$ & Silesian-Cracow $\mathrm{Zn}-\mathrm{Pb}$ mine area, Poland & $0.16-3.24$ & & Paulo et al. (2002) \\
\hline AMD waters $(\mu \mathrm{g} / \mathrm{L})$ & $\begin{array}{l}\text { Valdicastello Carducci-Pietrasanta, N } \\
\text { Tuscany, Italy }\end{array}$ & $200-9000$ & - & $\begin{array}{l}\text { Petrini et al. (2016), Campanella } \\
\text { et al. (2016) }\end{array}$ \\
\hline AMD waters $(\mu \mathrm{g} / \mathrm{L})$ & Iron Mountain, N California & $150-1600$ & - & Alpers et al. (2003) \\
\hline AMD waters $(\mu \mathrm{g} / \mathrm{L})$ & Pollone mine, $\mathrm{N}$ Tuscany, Italy & $107-1000$ & 266 & Perotti et al. (2018) \\
\hline AMD waters $(\mu \mathrm{g} / \mathrm{L})$ & M. Arsiccio mine, N Tuscany, Italy & $7.3-856$ & 475 & \\
\hline AMD water $(\mu \mathrm{g} / \mathrm{L})$ & $\mathrm{Cu}$ mine, Shanxi, China & 1520 & - & Zhang 2017 cf. Liu et al. (2019a) \\
\hline AMD pit water $(\mu \mathrm{g} / \mathrm{L})$ & Xingren Hg-Tl mine, Lanmuchang area, & $26.6-26.9$ & - & Xiao et al. (2003, 2004a,b, 2012) \\
\hline AMD groundwaters $(\mu \mathrm{g} / \mathrm{L})$ & Guizhou, China & 13-1966 & - & \\
\hline AMD surface waters $(\mu \mathrm{g} / \mathrm{L})$ & & $1.9-8.1$ & - & \\
\hline AMD pools $(\mu \mathrm{g} / \mathrm{L})$ & Wiśniówka mine area, Poland & $<0.01-32.6$ & 12.27 & Migaszewski et al. (2019) \\
\hline Wastewater $(\mu \mathrm{g} / \mathrm{L})$ & Zn-facility, Jiangxi, China & $3000-1500^{\mathrm{a}}$ & - & Liu et al. (2019a) \\
\hline Wastewater $(\mu \mathrm{g} / \mathrm{L})$ & $\mathrm{Pb}-\mathrm{Zn}$ smelter, Guangdong, China & $470-370^{\mathrm{a}}$ & - & \\
\hline Pond $(\mu \mathrm{g} / \mathrm{L})$ & & 354.1 & & \\
\hline
\end{tabular}

${ }^{\mathrm{a} B e f o r e}$ and after lime treatment

waters of Europe vary from $<0.002$ to $7.90 \mu \mathrm{g} / \mathrm{L}$ with a mean of $0.477 \mu \mathrm{g} / \mathrm{L}(\mathrm{n}=807)$ (Salminen et al. 2005). It is interesting to note that Miocene colored groundwaters of the Central Wielkopolska region (west-central Poland) are characterized by dissolved $\mathrm{Tl}$ concentrations in the range of 0.004 to $0.47 \mu \mathrm{g} / \mathrm{L}$ with a median of $0.11 \mu \mathrm{g} / \mathrm{L}$. However, total $\mathrm{Tl}$ concentrations, including suspended solids, are much higher varying from 0.44 to $26 \mu \mathrm{g} / \mathrm{L}$ with a median of $4.05 \mu \mathrm{g} / \mathrm{L}$ (Wojtkowiak et al. 2016). This indicates that some of these aquifers cannot be extracted because $\mathrm{Tl}$ concentrations exceed permissible regulatory levels $(2 \mu \mathrm{g} / \mathrm{L})$ for drinking waters set by the U.S. Environmental Protection Agency (USEPA 2003) and other national regulatory agencies. 
In seawater, this element forms two chemical species: predominant $\mathrm{Tl}^{+}$and subordinate dissolved complexes $\mathrm{TlCl}^{0}$ (Byrne 2002; Nielsen et al. 2009; Turner et al. 2010). The geochemical abundance of thallium in seawater varies from 0.2 to $20 \mathrm{ng} / \mathrm{L}$ with a mean of $1.3 \pm 1 \mathrm{ng} / \mathrm{L}$ (Rehkämper and Nielsen 2004; Enghag 2004; Nielsen et al. 2006). It was found that rivers, hydrothermal and volcanic activity, airborne mineral particulates, and continental margin sediments are the principal fluxes of thallium to seawater (Rehkämper and Nielsen 2004). The recent oceanic residence time of $\mathrm{Tl}$ in the oceanic water is $\sim$ 18,500 years (Rehkämper and Nielsen 2004; Baker et al. 2009; Nielsen et al. 2017), which is substantially longer than the oceanic water mixing time of $\sim 1500$ years.

The study of northwestern German coastal waters documented seasonal and spatial variations in dissolved thallium concentrations from $\sim 5.1$ to $12.3 \mathrm{ng} /$ $\mathrm{L}$. The tidal $\mathrm{Tl}$ variations and low $\mathrm{Tl}$ levels in the water column may have been induced by removal of this metals from pore waters in reducing sediments and release of Tl-free and $\mathrm{Mn}$-rich pore waters during low tides. The negative $\mathrm{Tl}$ anomaly was observed at over $40 \mathrm{~km}$ to the island of Helgoland. This means that thallium does not behave conservatively in seawater (Böning et al. 2018).

Sometimes water pipelines may become secondary source of thallium contamination as substantiated by the Valdicastello Carducci-Pietrasnta study in northern Tuscany, Italy (Biagioni et al. 2017). The rust scales, composed mostly of Fe oxyhydroxides with an admixture of $\mathrm{Mn}$, contained up to $5.3 \mathrm{wt} \% \mathrm{Tl}$. These scales consisted of nano- and microspherules of $\mathrm{Tl}_{2} \mathrm{O}_{3}$ with subordinate nanocrystalline $\mathrm{TlCl}$ encrustations. Results of X-ray absorption spectroscopy (XAS) analysis suggested that $\mathrm{Tl}^{+}$ions in water came from dissolution of $\mathrm{TlCl}$ coatings.

\subsection{Acid mine/rock drainage}

The acid mine drainage (AMD), or the naturally induced Acid Rock Drainage (ARD), is the most significant process responsible for remobilization of metal(loid)s from sulfide ore deposits and mineralized rock formations. This process is initiated by oxidation of pyrite $\left(\mathrm{FeS}_{2}\right)$, and to a lesser extent by different iron-bearing sulfides, as a result of metal sulfide ore and coal mining and processing, in places by dam or highway construction works exposing metal sulfide mineralization zones (e.g., Alpers et al. 2003; Knöller et al. 2004; Romero et al. 2010; Nordstrom 2011b; Migaszewski et al. 2018). The AMD (ARD) generates sulfuric acid and various pyrite oxidation products that trigger a sequence of physical, chemical, mineralogical and biological feedback processes leading to accumulation of toxic metal(loid)s in waters, sediments, soils, and biota.

The mine tailings spill accidents have posed a threat to the environment in many sites all over the world (Nordstrom 2011a, b). Acidic waters and mud are typically abundant in toxic metal(loid)s including thallium. One of these examples was a catastrophic dam breach of the Aznalcollar tailings pond (southwest Spain) in 1998 that released about 4 million cubic meters of acidic water and 2 million cubic meters of toxic mud into the Agrio River and subsequently the Guadiamar River. The metal(loid)rich mud alone contained $0.005 \% \mathrm{Tl}$ (Grimalt et al. 1999).

There are only a few published reports that focus on concentrations of thallium in AMD areas, hence relatively little is known about the occurrence of $\mathrm{Tl}$ chemical species and their behavior in these extreme environments. Apart from dominant $\mathrm{Tl}^{+}$ions, this element may also form complexes not only with prevailing sulfates, but also with carbonates, arsenates, chlorides and nitrates as suggested by Zhang et al. (1998) and Cidu (2011). In contrast to most metal(loid)s, thallium is only slightly adsorbed onto and coprecipitated with predominant $\mathrm{Fe}$ - and $\mathrm{Al}$-oxyhydroxides (Casiot et al. 2011). However, in reducing environments, this element can easily undergo adsorption onto and co-precipitation with Fe sulfide colloids (Laforte et al. 2005).

Thallium concentrations in AMD mine and tailings effluents vary from several through hundreds of $\mu \mathrm{g} / \mathrm{L}$ and are primarily associated with Tl-rich sulfides (e.g., Zitko 1975; Xiao et al. 2003; Casiot et al. 2011; Perotti et al. 2018). The most extreme AMD seeps and pools of the Iron Mountain massive sulfide deposit (northern California, USA) contained up to $1600 \mu \mathrm{g} / \mathrm{L} \mathrm{Tl}$ (Alpers et al. 2003). In the Tl-As-Hg-Au mineralized area of southwestern Guizhou Province (China), concentrations of $\mathrm{Tl}$ in groundwaters varied from 13 to $1966 \mu \mathrm{g} / \mathrm{L}$ whereas in stream waters from 1.9 to $8.1 \mu \mathrm{g} / \mathrm{L}$ (Table 2). The high levels of $\mathrm{Tl}$ (up to $1000 \mu \mathrm{g} / \mathrm{L}$ ) were also found in the Baccatoio Stream 
of northern Tuscany. As a result of dilution, the maximum $\mathrm{Tl}$ concentration dropped downstream reaching $\sim 4 \mu \mathrm{g} / \mathrm{L}$ near the coastline and $0.5 \mu \mathrm{g} / \mathrm{L}$ in a mixing zone with seawater (Perotti et al. 2018). However, the worldwide highest Tl levels $(9000 \mu \mathrm{g}$ / L) were found in strongly acidic water ponds $(\mathrm{pH}$ of 1.5-2.0) in abandoned mine adits located in the Valdicastello Carducci and Pietrasanta area, northern Tuscany, Italy. These underground waters jeopardize the quality of potable water used by local community (Petrini et al. 2016; Campanella et al. 2016, 2017; D'Orazio et al. 2020). The main source of water pollution is a pyrite ore containing $100-600 \mathrm{mg} / \mathrm{kg} \mathrm{Tl}$ (Biagioni et al. 2013). The other AMD sites are not so abundant in thallium, for example, concentrations of $\mathrm{Tl}$ in strongly acidic ( $\mathrm{pH}$ 1.4-2.2) and extremely Asrich pools of the Wiśniówka AMD area (south-central Poland) varied from $<0.01 \mu \mathrm{g} / \mathrm{L}$ to $32.6 \mu \mathrm{g} / \mathrm{L}$ (Migaszewski et al. 2019). Similarly, the False Wager Creek of the Drenchwater $\mathrm{Zn}-\mathrm{Pb}-\mathrm{Ag}$ sulfide ore deposit (north-central Alaska), showed a range of $<0.04$ to $89 \mu \mathrm{g} / \mathrm{L} \mathrm{Tl}$ as reported by Graham and Kelley (2009).

This and other studies have indicated that thallium (like dissolved sulfates) behaves conservatively and is only partly adsorbed onto Fe-Al hydroxide colloids, being transported primarily in the form of dissolved ions or different complexes (Cidu 2011). This is the reason why this metal is practically not removed by a hydroxide treatment technique (Law and Turner 2011). The same trend was also observed in the AMD waters of the of Cornwall county (southwestern England), where effluents of abandoned South Crofty tin mine were enriched in $\mathrm{Tl}(2640 \mathrm{ng} / \mathrm{L})$ as opposed to rivers (with regional baseline of $13 \mathrm{ng} / \mathrm{L} \mathrm{Tl}$ ) whose catchments were located in areas with a minimum mining activity (Tatsi and Turner 2014).

It should be stressed that the high $\mathrm{Tl}$ concentrations mentioned above occur directly at a pollution source, e.g., various acidic seeps, pools or ponds linked to mine adits and workings, tailings piles, or mineralization zone outcrops. Streams and rivers flowing through mining areas are usually depleted in thallium compared to AMD waters as evidenced by the study from six mining districts of the Republic of North Macedonia. The concentration of this element varied from 0.2 to $1.5 \mu \mathrm{g} / \mathrm{L}$ decreasing downstream (Alderton et al. 2005). These variations in the AMD water geochemistry are linked to a large extent to local lithology and mineralogy of host rock formations. The strongly acidic pyrite oxidation products react with different Tl-bearing sulfide and gangue minerals releasing this element to the environment. For example, the Iron Mountain volcanogenic massive sulfide (VMS) deposit of Kuroko type (Albers and Bain 1985) is a source of far larger amounts of thallium than the Wiśniówka Upper Cambrian stratiform As-rich pyrite mineralization zone occurring within sedimentary siliciclastic rocks (Migaszewski and Gałuszka 2019).

\subsection{Atmosphere}

The average content of thallium in the air does not exceed $1 \mathrm{ng} / \mathrm{m}^{3}$ (Peter and Viraraghavan 2005). Thallium is a highly volatile element at high temperatures and is released into the atmosphere in the form of fly ash, vapors and liquids during cement manufacturing, metal sulfide ore smelting, or largely through industrial and domestic coal combustion due to the lack of efficient emission control facilities. According to López Antón (2013), during combustion about $40 \% \mathrm{Tl}$ can be attributed to a gas phase and $60 \% \mathrm{Tl}$ to fly ash. For example, an ash sample taken from furnace stack filters and a sintering furnace of the "Bolesławiec" mining-metallurgical plant (southcentral Poland) contained on an average of $882 \mathrm{mg} /$ $\mathrm{kg} \mathrm{Tl}$ and up to 5\% Tl, respectively (Kicińska 2009). Airborne Tl-rich ash particulates are of great concern because they are deposited in soils, sediments, waters, and plants, and have potentially detrimental effects on biota and human health.

As a result of long-range airborne transport, Canadian Arctic snow and ice showed a mean value of $0.8 \mathrm{ng} / \mathrm{L} \mathrm{Tl}$ (Cheam 2001). One of the most interesting study, which documented the influence of meteorological conditions on $\mathrm{Tl}$ deposition, was performed by Krachler et al. (2008). Based on 567 ice, firn and snow samples collected from the Devon Ice Cap, Canadian High Arctic, they recorded a trend in $\mathrm{Tl}$ atmospheric long-range variations spanning 16,000 years. Concentrations of $\mathrm{Tl}$ varied from 0.03 to $3.40 \mu \mathrm{g} / \mathrm{kg}$ being the highest during the Younger Dryas period that was characterized by sparse vegetation, cold climate and high wind strengths, and consequently increased soil dust (and $\mathrm{Tl}$ ) accumulation. The background $\mathrm{Tl} / \mathrm{Sc}$ ratio for the oldest ice samples $(15,010-10,590$ year. BP) was far lower $(0.11 \pm 0.03)$ than in the modern (1994-2004) snow 
pit samples ( $\sim 0.5-2.0)$. Based on the analysis of snow pit samples, Krachler and coauthors (2008) estimated that $90 \%$ of $\mathrm{Tl}$ deposited on the Devon Ice Cap was derived from remote anthropogenic sources in spite of the seasonal input variations, being the greatest during winters.

Kellerhals et al. (2010) studied ice cores from the Nevado Illiman glacier (Bolivia) using thallium as a tracer of preindustrial volcanic eruptions that spanned the last 2000 years. They obtained four Tl peaks that may have fingerprinted four massive explosive eruptions of: (i) "unknown 1258" volcano, (ii) Kuwae ( 1450), (iii) Tambora (1815), and (iv) Krakatoa (1883). The concentration enrichment factor (EF) computed as: $(\mathrm{Tl} / \mathrm{U})_{\text {ice core }} /(\mathrm{Tl} / \mathrm{U})_{\text {Earth's crust }}$ varied from 6 ("1258" signal) to 30 (Tambora signal). The first signal was presumably linked to the Samalas volcano that erupted in 1257 on the Indonesian island of Lombok. The volcanic ash plumes reached the stratosphere and spread throughout the world.

Biomonitoring study of the moss species Hylocomium splendens from Norway pointed to a longrange transport of pollutants from different parts of Europe. Concentration of thallium in 458 moss samples varied from 0.0022 to $1.4 \mathrm{mg} / \mathrm{kg}$, with a mean of $0.12 \pm 0.15 \mathrm{mg} / \mathrm{kg}$ (Berg and Steinnes 1997). The comparative moss Pleurozium schreberi study performed in 1975 and 2000 in the southern part of Sweden showed a distinct decrease of Tl levels from $0.152 \pm 0.033 \mathrm{mg} / \mathrm{kg} \quad$ to $\quad 0.066 \pm 0.023 \mathrm{mg} / \mathrm{kg}$ (Rühling and Tyler 2004). Another biomonitoring study conducted on the predominant moss species Pleurozium schreberi and Scleropodium purum from 250 sites in the Czech Republic exhibited variations in $\mathrm{Tl}$ concentrations from $<0.06 \mathrm{mg} / \mathrm{kg}$ in areas of small deposition loads to $>0.21 \mathrm{mg} / \mathrm{kg}$ in highly contaminated areas (Sucharová and Suchara 2004).

\subsection{Vegetation}

Thallium is a non-essential element to plants (Robinson and Anderson 2018) and its average concentration in land plants is usually $<0.1 \mathrm{mg} / \mathrm{kg}$ dry weight (DW) whereas in edible plants varies from 0.02 to $0.125 \mathrm{mg} / \mathrm{kg}$ DW (Smith and Carson 1977). Trees and herbages contain more Tl than other plants (KabataPendias and Pendias 2011). Subalpine trees and shrubs from the Rocky Mountains comprised (in ash weight, AW) 2-100 mg/kg Tl (Shacklette et al. 1978). Based on U.S. plant studies, Carson and Smith (1977) regarded $\mathrm{Tl}$ concentrations in the range of $2-7 \mathrm{mg}$ / $\mathrm{kg}$ in ash as anomalous and $\geq 10 \mathrm{mg} / \mathrm{kg}$ as highly anomalous.

Bioavailability and bioaccumulation of thallium by individual plants is highly variable and depends on plant species, and on edaphic (soil chemistry and mineralogy), climatic, topographic and hydrologic factors. Climatic factors (temperature, precipitation, insolation, wind rose) are in turn affected by the northern-southern aspect, phenology and seasonal changes (Dunn et al. 1992). Many of these factors are largely unpredictable because they are additionally overlapped by physiologic and genetic variables. Another important issue, which must also be considered when assessing overall toxicity of plant species, is synergism linked to associated toxic elements. For example, the Lanmuchang study showed that aside from Tl (120-495 mg/kg, DW), green cabbage also contained a variety of other potentially toxicants ( $\mathrm{mg} /$ $\mathrm{kg}$, DW given in parentheses): As (0.38-0.89), Ba (46-90), Cd (0.17-0.35), Cr (0.31-0.74), $\mathrm{Hg}$ (0.38-0.72), Mo (0.6-1.2) and $\mathrm{Pb}(0.5-2.1)$, and additionally essential metals, e.g., $\mathrm{Cu}$ (2.7-7.9) and Zn (32-92), which may provide both synergistic and antagonistic effects (Xiao et al. 2004a).

The type of industrial emission source has also an influence on $\mathrm{Tl}$ bioavailability, for example, $\mathrm{Tl}$ in cement dust is more readily bioavailable than $\mathrm{Tl}$ from soils (Kazantzis 2000). Holubík et al. (2020) observed two times higher bioaccessibility of $\mathrm{Tl}$ to the hyperaccumulator species Sinapis alba L. (white mustard) growing in the soil substrate compared with its hydroponic equivalent. Another study performed on Sinapis alba L by Vaněk et al. (2011) showed that birnessite $\delta-\mathrm{MnO}_{2}$ immobilized and adsorbed Tl more effectively than illite, thus lowering bioavailability of this element. This experiment indicated that birnessite might find application in remediation of Tl-contaminated circumneutral or moderately acidic soils. In another experiment, Vaněk et al. (2013) demonstrated that $S$. alba growing on modified illite-rich soil showed the highest uptake of thallium as opposed to birnessite. In contrast to more stable goethite, dissolution of synthetic calcite and ferrihydrite in the rhizosphere-like environment favored $\mathrm{Tl}$ mobilization. These results indicated that soil mineralogy played a decisive role in phytoavailability of this metal. 
The highest concentrations of thallium (1.7\%) were recorded in the ash of bedstraw (Galium verum) growing on Tl-bearing soils of the Alsar district in the Republic of North Macedonia. The concentrations of thallium, ranging hundreds of $\mathrm{mg} / \mathrm{kg}$, were found in the plant species of the Brassicaceae (mustard) family (Robinson and Anderson, 2018). Another herbaceous plant, toadflax (Linaria vulgaris) contained as much as 3000 to $3800 \mathrm{mg} / \mathrm{kg}$ Tl DW (Zýka 1972). Of the other Tl hyperaccumulating plants, two plant species should be mentioned: brassicaceous Iberis intermedia Guersent (candytuft) that contained up to $4,055 \mathrm{mg} / \mathrm{kg} \mathrm{Tl}$ DW and Biscutella laevigata L. with $13,768 \mathrm{mg} / \mathrm{kg} \mathrm{Tl}$ DW growing on lead-zinc ore mine tailings near Montpellier, France (Leblanc et al. 1999). A threshold concentration of $100 \mathrm{mg} / \mathrm{kg} \mathrm{Tl}$ was proposed for plant hyperaccumulators (Van der Ent et al. 2013). These two plant species accumulate thallium in excessive amounts and can be used for both soil remediation and phytomining of brownfields and other derelict sites.

Plants and crops growing in sulfide ore mining areas also show a distinct abundance in thallium, for example in the Lanmuchang $\mathrm{Hg}$-Tl-As area (China) in the range of $0.78 \mathrm{mg} / \mathrm{kg}$ (corn) to $495 \mathrm{mg} / \mathrm{kg}$ (green cabbage) surpassing concentrations of this elements in soils (40-124 mg/kg) (Table 3). This indicates that concentrations of $\mathrm{Tl}$ in plants are species-dependent if they grow in the same environmental conditions. The enrichment factor ( $\mathrm{Tl}$ concentration ratio in crops vs. parent soils) for green cabbage exceeded 1 reaching 11. By comparison, the green cabbage from unpolluted areas contained about $0.4 \mathrm{mg} / \mathrm{kg} \mathrm{Tl}$ (Xiao et al. 2004a). The contents of $\mathrm{Tl}$ in different plants growing in the Lanmuchang mine district versus the control area are presented in Table 3. An interesting thing is that in the early growing stage, green cabbage showed far lower $\mathrm{Tl}$ contents varying from 15 to $32 \mathrm{mg} / \mathrm{kg}$. This means that this specific edible plant species has enormous Tl-binding capacity increasing with age. Much lower $\mathrm{Tl}$ concentrations were observed in vegetables, corns, and pine needles (0.01-0.20 mg/ $\mathrm{kg}$ DW) in the Xiangquan unmined near-surface Tlore deposit in the Anhui Province, East China (Zhou et al. 2008). Although pyrite in this mineral ore deposit was characterized by very high $\mathrm{Tl}$ contents ranging from 213.4 to $7,717 \mathrm{mg} / \mathrm{kg}$, these levels were not mirrored in farmland soils $(0.39-6.87 \mathrm{mg} / \mathrm{kg})$.

Many laboratory and hothouse experiments were performed to assess the uptake and accumulation of thallium by different plant species from artificially contaminated soils and waters in cultivated areas (e.g., Krasnodębska-Ostręga et al. 2012; Renkema et al. 2014; Ferronato et al. 2016). For example, an 80-day long experiment carried out on Mediterranean horticultural crops (basil, mint and strawberry) showed that a $\mathrm{Tl}$ content in rhizosphere depends on plant species metabolism. Of the three species examined, after 80 days, the strawberry exhibited both the highest $\mathrm{Tl}$ concentration $(251.7 \mathrm{mg} / \mathrm{kg}$ ) and percentage of $\mathrm{Tl}$ translocation from root to leaves whereas the mint the lowest (Ferronato et al. 2016).

\subsection{Microorganisms}

Bacteria, algae and fungi may bring about various interactions with abiotic systems affecting geoavailability, mobility, dispersivity, bioaccessibility and bioavailability of thallium by direct enzymatic or indirect nonenzymatic actions, including redox processes, chelatization by metabolites, biotransformation, and biodegradation of $\mathrm{Tl}$ complexes with ligands, biosorption by functional groups or formation of minerals. These biologically induced processes release this metal to water which is also a principal constituent of all plants, animals and man.

Studies conducted in the Yunfu AMD site (Yuncheng District, Guandong Province, south China) revealed that $\mathrm{Tl}$ polluted surface sediments with $\mathrm{Tl}$ concentrations in the range of 1.8 to $16.1 \mathrm{mg} / \mathrm{kg}$ were habitats for 50 phyla from the Bacteria domain and 1 phylum of the Archaea domain. They included the genera Acidithiobacillus, Ferroplasma, Ferrovum, Leptospirillum, Metallibacterium and Sulfuriferula (Liu et al. 2019b), typically encountered in pyrite oxidation environments. The authors also evidenced the positive correlation between $\mathrm{Tl}$ concentrations and an amount of acidophilic Fe-metabolizing species.

Rasool et al. (2020) characterized microbial communities from Tl-contaminated riverbank soils from the Lanmuchang mine district, Guizhou Province (China). They found a high microbial biodiversity in the examined soil and suggested that microorganisms of the genus Nocardioides, order Actinomycetales, phylum Ralstonia and genus Sphingomonas are tolerant to high $\mathrm{Tl}$ concentrations, which may be important for their potential use in bioremediation of Tlcontaminated soils and sediments. A high efficiency of $\mathrm{Tl}$ removal (up to $99.6 \%$ ) from AMD soils by a 
Table 3 Concentrations of thallium in plants and crops under natural and man-induced conditions (mg/kg, dry weight, or otherwise indicated)

\begin{tabular}{|c|c|c|c|c|}
\hline Plants and crops & Locality & Range/Value & Mean & References \\
\hline Vegetables & \multirow[t]{3}{*}{ Uncontaminated areas } & $0.02-0.125$ & - & \multirow[t]{3}{*}{ Smith and Carson (1977) } \\
\hline Clover & & $0.008-0.01$ & - & \\
\hline Meadow hay & & $0.02-0.025$ & - & \\
\hline Most vegetables & $\begin{array}{l}\text { Uncontaminated areas, USA } \\
\text { (contents in ash, AW) }\end{array}$ & $0.4-0.5$ & & Carson and Smith (1997) \\
\hline Subalpine fir needles & \multirow[t]{10}{*}{ Rocky Mts., USA (AW) } & $2-100$ & - & \multirow[t]{10}{*}{ Shacklette et al. (1978) } \\
\hline Subalpine fir stem & & $2-70$ & - & \\
\hline Engelmann pine needles & & $2-10$ & - & \\
\hline Engelmann pine stems & & 15 & - & \\
\hline Limber pine needles & & $2-5$ & - & \\
\hline Limber pine stems & & $3-5$ & - & \\
\hline Lodgepole pine needles & & $2-5$ & - & \\
\hline Lodgepole pine stems & & $3-7$ & - & \\
\hline Myrtle blueberry stems and leaves & & $2-7$ & - & \\
\hline Ponderosa pine stem & & 15 & - & \\
\hline Chinese cabbage & \multirow{13}{*}{$\begin{array}{l}\text { Lanmuchang Tl-ore mining } \\
\text { area, China }\end{array}$} & $0.87-5.4$ & 2.5 & \multirow[t]{13}{*}{ Xiao et al. (2004a) } \\
\hline Background values & & - & 0.31 & \\
\hline Green cabbage & & $120-495$ & 338 & \\
\hline Background values & & - & 0.4 & \\
\hline Chili & & $0.8-5.3$ & 3.0 & \\
\hline Background values & & - & 0.27 & \\
\hline Granular corn & & $0.78-3.1$ & 1.43 & \\
\hline Background values & & $0.05-0.09$ & - & \\
\hline Shelled rice & & $1.0-5.2$ & 2.4 & \\
\hline Background values & & - & 0.27 & \\
\hline Carrot root & & 22 & - & \\
\hline Fern leaf & & 15 & - & \\
\hline Wild herbs & & $25-47$ & 36 & \\
\hline Crops (garlic .... rice) & \multirow{2}{*}{$\begin{array}{l}\text { Xiangquan Tl-ore unmined } \\
\text { area, China }\end{array}$} & $0.01-0.20$ & - & \multirow[t]{2}{*}{ Zhou et al. (2008) } \\
\hline Pine needles & & 0.019 & - & \\
\hline Birch buds & Bukowno-Olkusz Zn-Pb & $9.4-12.6$ & - & \multirow[t]{3}{*}{ Karbowska (2016) } \\
\hline Birch trunk juice $(\mu \mathrm{g} / \mathrm{L})$ & mining area, Poland & $89-145$ & - & \\
\hline Grass & & - & 25.5 & \\
\hline
\end{tabular}

sulfate reducing bacterium Citrobacter freundii was documented by Zhang et al. (2017).

A study conducted by Sun et al. (2012) showed that some bacteria cultures, filamentous fungi and actinomyces were tolerant of very high $\mathrm{Tl}$ levels (up to $1000 \mathrm{mg} / \mathrm{kg}$ ), maintaining their metabolic activities in Tl-polluted soils of the Guizhou Province. These authors identified nine fungal strains of the genera Trichoderma, Penicillium, Paecilomyces and Mariannaea, which might be useful for bioremediation of highly contaminated soils and waters. Birungi and Chirva (2015) used the green algae Scenedesmus acuminutus, Chlorella vulgaris and Chlamydomonas reinhardtii to evaluate their sorption potential and 
recovery of thallium. At a higher $\mathrm{Tl}$ concentration $(250-500 \mathrm{mg} / \mathrm{L})$, these algal species achieved removal capacity at a range of 830 to $1000 \mathrm{mg} / \mathrm{g}(C$. vulgaris), and high recovery of $\mathrm{Tl}$ amounting to $\geq 93 \%$. Thallium was bound on the algal cell walls primarily by carboxyl and phenol functional groups.

\subsection{Animals}

Thallium exhibits acute and chronic toxicity to nearly all living organisms (Kazantzis, 2000; Peter and Viraraghavan, 2005). Toxicity of $\mathrm{Tl}^{+}$to organisms depends on the species examined ranging from $\mu \mathrm{g} / \mathrm{L}$ to mg/L (e.g., Zitko et al. 1975; Rickwood et al. 2015). Tl ions can substitute for $\mathrm{K}^{+}$, in the activation of the $\mathrm{Na}^{+}$/ $\mathrm{K}^{+}$ATPase pumps, then move through cell membranes, accumulate in cells and then attack the mitochondrial respiratory chain (e.g., Spencer et al. 1973; Osorio-Rico et al. 2017; Maya-López et al. 2018). Energy depletion, oxidative damage, and $\mathrm{Na}^{+} /$ $\mathrm{K}^{+}$ATPase pump inhibition may lead to $\mathrm{Tl}^{+}$toxic effects in nerve terminals (Maya-López et al. 2018).

However, this metal tends to accumulate in some living organisms, leading to considerable biomagnification in a food chain. For example, the study of troutperch (Percopsis omiscomaycus) from the Athabasca River (Canada), where a mean $\mathrm{Tl}$ concentration was $0.01 \mu \mathrm{g} / \mathrm{L}$, showed that this fish species bioaccumulates thallium in its otholits (Shotyk et al. 2019). The $\mathrm{Tl}$ enrichment ratio in otholits relative to water was in the range of 19-190. An interesting study on Tl transfer in the river food web consisting of four trophic levels in Northwest Territories (Canada) showed that $\mathrm{Tl}$ concentrations decreased by $54 \%$ with each step of the food chain in the subsequent trophic levels from periphyton through invertebrates and small fishes to large fishes (Jardine et al. 2019). The observed phenomenon suggests that $\mathrm{Tl}$ exhibits biodilution in the riverine food web.

Many thallium studies have been centered on different species occupying habitats impacted by geohazards or industrial pollution sources. One of the examples is the Aznalcóllar mining spill into the Guadalquivir River (SW Spain) that occurred in 1998. This had no distinct impact on thallium concentrations in four species: clam Scrobicularia plana (40-90 $\mu \mathrm{g}$ / $\mathrm{kg}$ ), fish Liza ramada (80-120 $\mu \mathrm{g} / \mathrm{kg})$, oyster Crassostrea angulata (15-98 $\mu \mathrm{g} / \mathrm{kg})$, and crab Uca tangeri (75-125 $\mu \mathrm{g} / \mathrm{kg}$ ). This study indicated that thallium was not bioavailable in the presence of Tl-polluted sediments (DelValls et al. 1999). However, after this ecological disaster, a study of white-toothed shrew Crocidura russula from the Doñana protected area showed a 3- and 10-fold increase of $\mathrm{Tl}$ in liver $(147 \pm 44.47 \mu \mathrm{g} / \mathrm{kg})$ and kidneys $(325.27 \pm 33.59 \mu \mathrm{g} / \mathrm{kg}) \quad$ vs. reference specimens accumulating $\quad 52.68 \pm 7.76 \mu \mathrm{g} / \mathrm{kg} \quad \mathrm{Tl}$ and $33.32 \pm 7.63 \mu \mathrm{g} / \mathrm{kg} \mathrm{Tl}$, respectively (Sánchez-Chardi 2007). Moreover, adults exhibited higher Tl concentrations than juveniles, likewise females compared to males.

Lengthy exposure to $\mathrm{Tl}$ emissions also induced harmful effects on small forest mammal population of 106 individuals as documented by a bioindication study in the neighborhood of the zinc smelter "Bolesław" in southern Poland (Dmowski et al. 1998). Very high Tl levels occurred in livers and kidneys of all mammals from two areas located near the smelter. The bank vole's species Clethrionomys glareolus exhibited the highest concentrations of thallium in kidneys and livers reaching as much as $34.27 \mathrm{mg} / \mathrm{kg}$ (DW) and $14.5 \mathrm{mg} / \mathrm{kg} \mathrm{Tl}$ (DW), respectively $(0.07 \mathrm{mg} / \mathrm{kg}$ in a control unpolluted area). Several individuals showed a decreased amount of hair and in one case a wood mouse (Apodemus sylvaticus) had its half rear body nearly hairless.

\section{Thallium isotopes in solving geologic and environmental issues}

Thallium contains only two stable isotopes with 203 and 205 atomic mass units and natural abundance $29.54 \%$ and $70.48 \%$, respectively (Rehkämper and Halliday 1999). These are used for isotope determinations due to their substantial fractionation $(\sim 3.5 \%)$ between $\mathrm{Fe}-\mathrm{Mn}$ nodules, crusts or efflorescences, which are abundant in ${ }^{205} \mathrm{Tl}$, and seawater (Nielsen et al. 2017). Aside from these two stable isotopes, 35 short-lived thallium radionuclides have so far been generated, including ${ }^{204} \mathrm{Tl}\left(\mathrm{t}_{1 / 2}=3.78\right.$ years $),{ }^{202} \mathrm{Tl}\left(\mathrm{t}_{1} /\right.$ $2=12.2$ days $)$ and ${ }^{201} \mathrm{Tl}\left(\mathrm{t}_{1 / 2}=73 \mathrm{~h}\right)$ (Belzile and Chen 2017).

In contrast to continental crust and Earth's mantle, modern oceanic water is enriched in the light isotope $\left({ }^{203} \mathrm{Tl}\right)$ and the $\varepsilon^{205} \mathrm{Tl}$ values (reported as $\left.{ }^{205} \mathrm{Tl} /{ }^{203} \mathrm{Tl}_{\text {sample }}-{ }^{205} \mathrm{Tl} /{ }^{203} \mathrm{Tl}_{\mathrm{NIST}-\mathrm{SRM} 997}\right) /\left({ }^{205} \mathrm{Tl} /{ }^{203-}\right.$ $\left.\mathrm{Tl}_{\text {SRM997 }} \times 10,000\right)$ ) vary from -6 to -5 with a 
mean of $-5.5 \pm 1.0$ due to scavenging of ${ }^{205} \mathrm{Tl}$ (caused by oxidation of $\mathrm{Tl}^{+}$to $\mathrm{Tl}^{3+}$ ) by authigenic $\mathrm{Fe}$ $\mathrm{Mn}$ oxyhydroxides that consequently show a mean $\varepsilon^{205} \mathrm{Tl}$ value of $+12.8 \pm 1.2$ (Rehkämper et al. 2002; Nielsen et al. 2005, 2006, 2009). This is the reason why ferromanganese nodules and crusts are ubiquitously enriched in the heavy ${ }^{205} \mathrm{Tl}$ isotope. For comparison, the mean $\varepsilon^{205} \mathrm{Tl}$ values for different Earth's environments are relatively uniform: -2.5 (volcanic gases), -2.5 (rivers), 0 (sediment porewaters), $-2.0 \pm 0.5$ (upper mantle), $-2.0 \pm 1$ (continental crust, detritic sediments), -12 to -6 (altered oceanic crust), -2.0 (hydrothermal fluids), and -2.0 (airborne mineral particulates/loess) (Rehkämper et al. 2002; Nielsen et al. 2005, 2006, 2011; Nielsen and Rehkämper 2011; Owens et al. 2017) (Fig. 4). It is noteworthy that the $\varepsilon^{205} \mathrm{Tl}$ values of rock-forming minerals (K-feldspars, micas) and sulfides vary from $-12.1 \pm 0.6$ to $+18.0 \pm 1.4$ (Rader et al. 2018) falling within the range of -20 to +15 reported by Nielsen et al. (2017). According to Howarth et al. (2018), weathering particularly combined with a groundwater table interaction induces some fractionation. However, it should be stressed that there are very few studies currently in most of these areas.

The main scavengers of thallium are ferromanganese nodules, crusts and encrustations that occur on the floor of oceans at a proximal or remote distance from hydrothermal vents. Of different Mn oxyhydroxide minerals, only hexagonal birnessite $\delta-\mathrm{MnO}_{2}$ oxidizes $\mathrm{Tl}^{+}$to $\mathrm{Tl}^{3+}$ during adsorption, thus being enriched in the heavy ${ }^{205} \mathrm{Tl}$ isotope (Peacock and Moon 2012). Hydrothermal ferromanganese deposits are characterized by a positive correlation between the $\mathrm{Mn} / \mathrm{Fe}$ ratios and $\varepsilon^{205} \mathrm{Tl}$ values. These deposits with the high $\mathrm{Mn} / \mathrm{Fe}$ and high $\varepsilon^{205} \mathrm{Tl}$ ratios are generated by adsorbing thallium from colder and distal hydrothermal vents (Rehkämper et al. 2002).

The marine Fe-Mn oxyhydroxide crusts precipitate very slowly with a rate of $15 \mathrm{~cm}$ per 80 million years, giving an opportunity to trace changes in seawater chemistry during the Cenozoic (Nielsen et al. 2009). Measurements of ${ }^{205} \mathrm{Tl} /{ }^{203} \mathrm{Tl}$ ratios in oceanic ferromanganese crusts recorded no diagenetic overprints or isotope fractionations with seawater, thus reflecting the $\mathrm{Tl}$ isotope composition of seawater over geologic time. Rehkämper et al. (2002), Rehkämper and Nielsen (2004) and Nielsen (2006) reported a systematic $\mathrm{Tl}$ isotope fractionation between the modern oceanic water and ferromanganese crusts. Based on the assumption that oceanic $\mathrm{Tl}$ budget remained unchanged during Cenozoic time, the low ${ }^{205} \mathrm{Tl} /{ }^{203} \mathrm{Tl}$ during the Paleocene $\left(\varepsilon^{205} \mathrm{Tl}=+6\right)$ may be elucidated by a four-fold higher removal rate of this

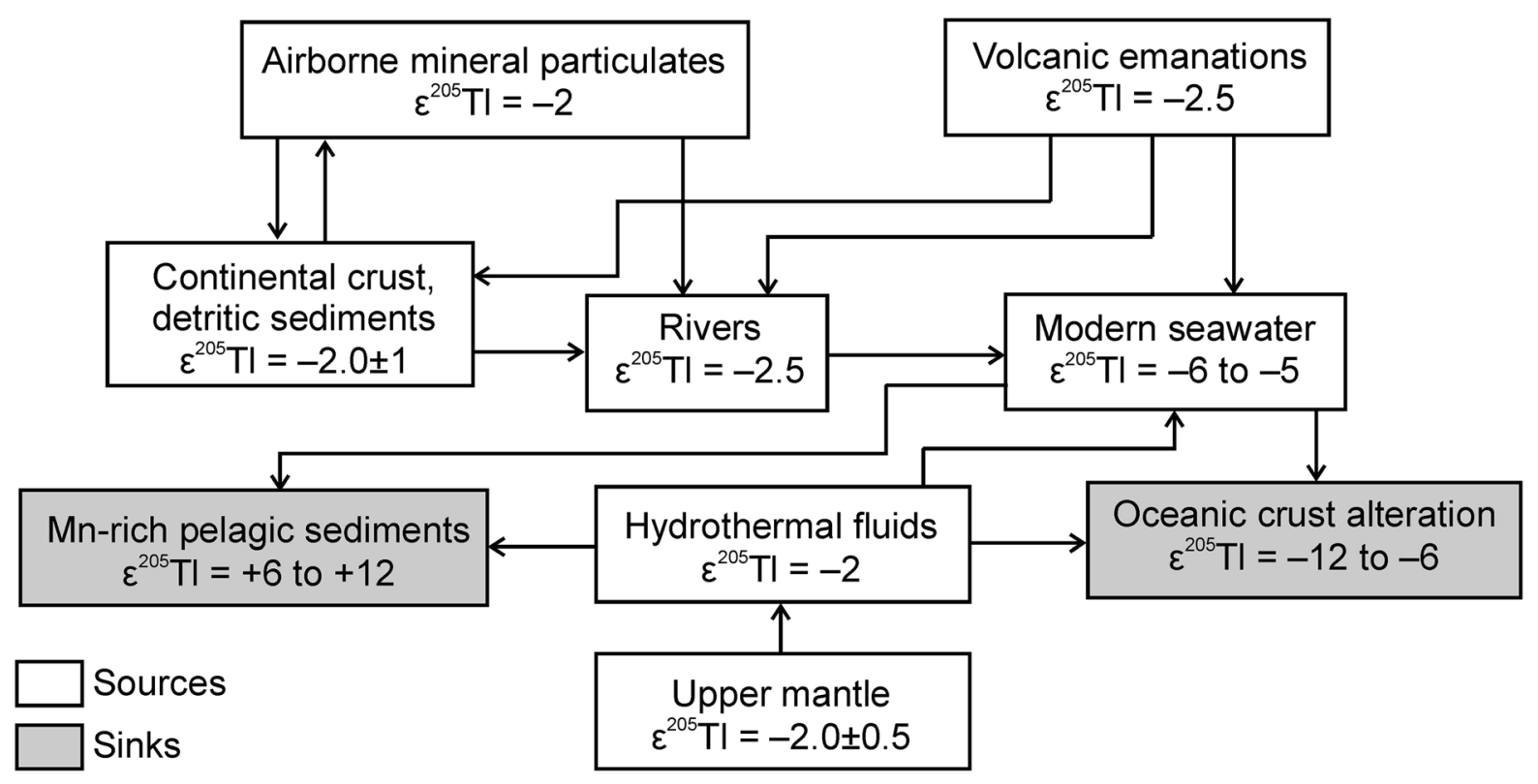

Fig. 4 Thallium isotope ratios in geoenvironmental compartments (compiled from Rehkämper et al. 2002 ; Nielsen et al. 2005, 2006, 2011; Nielsen and Rehkämper 2011; Owens et al. 2017) 
element from seawater via adsorption onto Fe-Mn oxyhydroxides compared to the present-day oceanic water, and partly by a low temperature alteration of oceanic crust (Rehkämper et al. 2002; Rehkämper and Nielsen 2004; Nielsen et al. 2009). The lower $\varepsilon^{205} \mathrm{Tl}$ values of $\mathrm{Fe}-\mathrm{Mn}$ precipitates may also correspond to the high $\mathrm{Tl}^{3+} / \mathrm{Tl}^{+}$ratios (Nielsen et al. 2006, 2009). This implies that thallium isotope variations in Fe-Mn crusts may serve as an oceanic paleoenvironmental proxy recording an extent of oxic marine sediments and a lack of anoxic (deficit in $\mathrm{O}_{2}$ and $\mathrm{H}_{2} \mathrm{~S}$ ) and euxinic (deficit in $\mathrm{O}_{2}$ and $\mathrm{H}_{2} \mathrm{~S}$ abundance) conditions (Owens et al. 2017; Bowman et al. 2019; Ostrander et al. 2019; Fan et al. 2020). The study of Ediacaran sediments ( 580-550 Ma) of the upper Doushantuo Formation (South China) documented more negative $\varepsilon^{205} \mathrm{Tl}$ values $(-7.8$ to -5.1$)$ than those of modern global seawater, which was linked to an expansion of oxic conditions and evolution of Ediacaran biota (Fan et al. 2020).

Another interesting application of stable thallium isotopes is an attempt to reconstruct Toarcian (Lower Jurassic) vs. Late Neogene paleoredox environments based on $\mathrm{Tl}^{3+} / \mathrm{Tl}^{+}$determinations in the early-diagenetic pyrite (Nielsen et al. 2011). According to these authors, the heavy ${ }^{205} \mathrm{Tl}$ isotope signature of Late Neogene pyrite points to ferromanganese concretions as a principal source of thallium supply whereas Yorkshire ${ }^{205}$ Tl-depleted pyrite indicates euxinic conditions and a lack of Fe-Mn precipitation (Toarcian Ocean Anoxic Event dated back to $\sim 183 \mathrm{Ma}$ ). Results of thallium isotope determinations were compared by Them II et al. (2018) with other indicators of paleoredox conditions during the Toarcian Ocean Anoxic Event for reconstruction of global oceanic deoxygenation. It was shown that $\mathrm{Tl}$ isotopes enabled tracking much earlier signals of oxygen depletion than those obtained with traditional approaches, i.e. a negative carbon isotope excursions, an appearance of organic-rich (black shale) facies, and a decrease in species diversity.

There is a paucity of data for most geologic environments, outside of marine settings. These data indicate that there is no isotope fractionation during leaching of thallium from basalts by submarine hydrothermal fluids, and additionally point to the homogenous $\varepsilon^{205} \mathrm{Tl}$ value of the continental crust as evidenced by isotope analysis of loess (Nielsen et al. $2005,2006)$. As opposed to the upper mantle, $\mathrm{Mn} / \mathrm{Fe}$ - rich pelagic sediments or a hydrothermally altered oceanic crust (Nielsen et al. 2006) show higher concentrations of thallium and distinct fractionations of its isotopes that range from +6 to +12 and from -12 to -6 , respectively (Nielsen and Rehkämper 2011; Nielsen et al. 2017). Thallium isotope ratios were also used to assess a contribution of the subducted low-temperature altered oceanic crust to the mantle heterogeneity as exemplified by the study of the HIMU (high $\mathrm{U} / \mathrm{Pb}$ ) mantle domains on the island of St. Helena in the Atlantic Ocean. The St. Helena lavas exhibited enrichment in $\mathrm{Tl}$ and a considerable variation of the $\varepsilon^{205} \mathrm{Tl}$ values $(-9.8$ to +3.9 ), but most of them were isotopically lighter than the Tl-depleted $(-2)$ and more homogenous upper mantle (Blusztajn and Nielsen 2018).

The thallium isotopes were also used to track subducted slab components in arc lavas, for example in the Ryukyu arc and its back-arc basin and the Okinawa Trough (Shu et al. 2017). Different sediment types sourced from Japan affected the average $\varepsilon^{205} \mathrm{Tl}$ isotope values of the Ryukyu arc lavas that varied from - 1.2 (detrital sediments from the outboard of the northern section) to +4.5 (pelagic sediments from the outboard of the central section). In contrast, lavas from the outboard of the south Ryukyu arc with the more systematic $\varepsilon^{205} \mathrm{Tl}$ of -2.0 were linked to detrital material sourced from Taiwan and additionally to loess from China. In turn, $\mathrm{Tl}$ isotope variations in the Okinawa Trough reflected those in the Ryukyu arc sections (Shu et al. 2017).

The $\varepsilon^{205} \mathrm{Tl}$ values were also used as a proxy for redox-controlled geochemical processes that took place during rock weathering and soil formation (Vaněk et al. 2020). This study was conducted on naturally Tl-rich soils developed on Fe-As-Tl mineralized dolomites at the locality Erzmatt (Swiss Jura Mts.). In two examined soil profiles, the horizon-B was abundant in ${ }^{205} \mathrm{Tl}$ showing the $\varepsilon^{205} \mathrm{Tl}$ value higher by 7 compared to that of the subjacent bedrock. Moreover, the exchangeable fraction of this soil horizon was distinctly enriched in ${ }^{205} \mathrm{Tl}$ than the bulk sample. This suggests multiphase complex processes of thallium mobilization, oxidation, immobilization and remobilization combined with isotope fractionation between different mineral phases with illite as a principal scavenger of ${ }^{205} \mathrm{Tl}$.

Thallium isotopes also found applications in tracing pollution point-sources and determining 
anthropogenic inputs of this element into different environmental compartments. However, little is still known about anthropogenic $\varepsilon^{205} \mathrm{Tl}$ imprints in the environment versus their geogenic equivalents, and (bio)geochemical $\mathrm{Tl}$ isotope fractionations in soils and biota (Kersten et al. 2014; Vaněk et al. 2015, 2016, 2018; Grösslova et al. 2018). A pioneer study of soils contaminated by cement plant emissions near Lengerich (Germany) showed enrichment in thallium as a result of using a Tl-rich pyrite roasting waste. The subsoil showed a typical geogenic $\varepsilon^{205} \mathrm{Tl}$ signature (roughly -4$)$, as opposed to the topsoil that was isotopically heavier $(\sim 0)$ reflecting the $\varepsilon^{205} \mathrm{Tl}$ value $(\sim 0)$ of pyrite. Moreover, an inverse linear relationship $\left(\mathrm{R}^{2}=0.82\right)$ was exhibited by a ratio of $\varepsilon^{205} \mathrm{Tl}$ to $1 /$ total $\mathrm{Tl}$ concentration in $\mathrm{HF}-\mathrm{HNO}_{3}$ digested soil samples. This is indicative of binary $\mathrm{Tl}$ mixing between two predominant pools: (i) the geogenic source with low $\mathrm{Tl}$ concentrations $(0.1$ to $0.2 \mathrm{mg} / \mathrm{kg}$ ) and an abundance in the light ${ }^{203} \mathrm{Tl}$ isotope $\left(\varepsilon^{205} \mathrm{Tl}=<-3.0\right)$ and (ii) the anthropogenic source characterized by higher $\mathrm{Tl}$ concentrations $(2.5 \mathrm{mg} / \mathrm{kg})$ and enrichments in the heavy ${ }^{205} \mathrm{Tl}$ isotope $\left(\varepsilon^{205} \mathrm{Tl}=>\right.$ - 1.0) (Kersten et al. 2014). This Tl isotope study also included a Tl-rich sulfide mineralization zone in Lanmuchang mine district, Guizhou Province (China), exhibiting a significant dispersion of the $\varepsilon^{205} \mathrm{Tl}$ values between topsoil (roughly 0.4) and green cabbage Brassica oleracea L. var. capitata L. (range of -5.4 to -2.5 ), which may be elucidated by anthropogenic $\mathrm{Tl}$ inputs (Kersten et al. 2014).

However, it should be stressed that the $\varepsilon^{205} \mathrm{Tl}$ ratios do not always give a basis for unambiguous interpretation, for instance, the more recent study showed considerable $\mathrm{Tl}$ isotope fractionation during smelting of pyrite ore for sulfuric acid production (Liu et al. 2020). The raw material and four processing wastes revealed the following $\varepsilon^{205} \mathrm{Tl}$ values: pyrite ore + 1.28, electrostatic precipitation fly ash -1.10 , cyclone fly ash +2.17 , boiler fly ash +8.34 and fluidized-bed furnace slag +16.24 . These large variations in $\mathrm{Tl}$ isotope composition may be brought about by both Rayleigh fractionation and adsorption.

The study of moderately contaminated forest and meadow soils in the area of lignite mining and coalfired power plants at the Czech-Germany-Poland border revealed at least partial $\mathrm{Tl}$ isotope fractionations between different media $\left(\varepsilon^{205} \mathrm{Tl}\right.$ values in parentheses): volatile $\mathrm{Tl}$ fractions (range of -10.3 to -6.2 ), fly ash (range of -2.8 to -2.5 ), bottom ash $(\sim 0)$ and soils $(+0.4)$ (Vaněk et al. 2016). In another study conducted near the Bolesław Zn smelter (Silesia-Cracow district, southern Poland), Vanĕk et al. (2018) exhibited small variations of the $\varepsilon^{205} \mathrm{Tl}$ values in contaminated soils (with over $50 \mathrm{mg} / \mathrm{kg} \mathrm{Tl}$ ) and various industrial wastes. Fly ash was isotopically lighter ( -4.1$)$ than local Zn sulfide ores $(-3.8)$, postflotation $\mathrm{Zn}-\mathrm{Fe}$ residue $(-3.9)$ or slags $(-3.3)$, and this isotope signature was well-preserved in contaminated topsoil (up to -3.8 ), despite the fact that peak pollution ended in the 1980s. Moreover, subsoil showed depletion in the light isotope with the $\varepsilon^{205} \mathrm{Tl}$ signature ranging from -2.7 to +0.4 .

The ${ }^{205} \mathrm{Tl} /{ }^{203} \mathrm{Tl}$ ratios were also used to trace an impact of flotation tailings dam with predominant sphalerite and pyrite on the desert soils of southern Namibia (Rosh Pinah) contaminated with thallium up to $7.6 \mathrm{mg} / \mathrm{kg}$ (Grösslova et al. 2018). The $\varepsilon^{205} \mathrm{Tl}$ values of these soils varied from -0.4 to +3.8 exhibiting a positive correlation coefficient $(0.62)$ with reciprocal $\mathrm{Tl}$ concentrations $(1 / \mathrm{Tl})$, which is indicative of both anthropogenic $\left(\varepsilon^{205} \mathrm{Tl}=\sim+3.6\right)$ and geogenic $\left(\varepsilon^{205} \mathrm{Tl}=\sim 0\right)$ inputs. The former value dominated in topsoil fingerprinting the $\varepsilon^{205} \mathrm{Tl}$ ratio of flotation tailings wastes (range of +1 to +3.8 ). This is also evidenced by distinct enrichment of $\mathrm{Tl}$ in topsoil ( 0.9 to $7.6 \mathrm{mg} / \mathrm{kg})$ in relation to subsoil $(0.7 \mathrm{mg} / \mathrm{kg})$.

Rader et al. (2019) showed that Brassica juncea (Indian mustard) fractionates $\mathrm{Tl}$ during its growth. Thallium was initially taken into the stem at an equal rate of ${ }^{203} \mathrm{Tl}$ and ${ }^{205} \mathrm{Tl}$, but then the stem was depleted in ${ }^{203} \mathrm{Tl}$ over time as new plant parts grew. This resulted in ${ }^{205}$ Tl-rich stem $(+2.5)$ and ${ }^{203}$ Tl-rich young plant parts $(-2.5$ to +0.1$)$. The light isotope ${ }^{203} \mathrm{Tl}$ undergoes easier transport to above-ground organs giving a similarity to $\mathrm{Tl}$ and $\mathrm{K}$ and a movement within the xylem.

\section{Conclusions}

Many case studies of thallium characteristics, occurrences and fate, including geologic mapping and bioindication, have generally shown no detrimental impact of this metal on the environment and human beings. The content of thallium in living organisms is usually low and is influenced by the geochemical and mineralogical nature of their habitat that in turn 
correlates with the geologic makeup of the Earth's crust. Bioavailability of this element is preceded by mineral and physicochemical speciation in waters, sediments, and soils. The only exception to this rule is some historical and recent mining and industrial areas where $\mathrm{Tl}$ concentrations typically exceed permissible regulatory levels for drinking waters and cultivable soils. Of these areas, AMD sites are the most hazardous to abiotic and biotic systems due to generation of acidic products of Tl-pyrite oxidation that react with other Tl-rich sulfide and gangue minerals releasing this metal to the environment. The presence of thallium in mine waters, sediments, soils and tailings is considered a hidden geoenvironmental health hazard because thallium is both nonessential and highly toxic to humans. This is the reason why the occurrence of different $\mathrm{Tl}$ species and their fate under variable redox conditions should be further investigated in these extreme environments, the more so as thallium is typically associated with other potentially toxic elements, including $\mathrm{As}, \mathrm{Cd}, \mathrm{Hg}, \mathrm{Pb}$ and $\mathrm{Sb}$.

Besides, still little is known about the behavior of secondary Tl-bearing minerals (e.g., illite, vermiculite, jarosite, Fe-Mn oxyhydroxides) and organic matter in controlling thallium solubility and mobility under different physicochemical conditions. There is some uncertainty surrounding this issue and many questions remain unsolved. Further research should enable us to better understand and assess a role of these natural sorbents in immobilization of thallium, especially in geochemically and mineralogically complex media like rock wastes and soils. This issue is closely linked to an impact of thallium on biota and humans in mineralized, mining, post-mining or other anthropogenically-impacted areas.

Future studies of cultivable plants growing within metal sulfide and coal mining areas should be conducted in many geochemical and mineralogical aspects, including release (geoavailability), weathering, transport, mobility, deposition and remobilization of thallium as well as mineral and physicochemical speciation preceding bioavailability. These should also involve the search for specific plant species showing enormous thallium-binding capacity. Some of them may be used in post-mining and derelict landreclamation without soil stripping.

There are growing studies involving determinations of stable $\mathrm{Tl}$ isotope ratios in different geologic and environmental materials, including minerals, rocks, soils, sediments, plants and mining and processing wastes. However, results obtained are not always straightforward and are often complex and obscured due to the lack of a broad $\mathrm{Tl}$ isotope database as opposed to the stable $\mathrm{C}, \mathrm{O}, \mathrm{S}$ isotope databases that have been compiled for decades. The stable $\mathrm{Tl}$ isotope signatures of manganese concretions and crusts, and pyrite have been used for studying recent and past geologic processes and served as proxies for reconstruction of marine and terrestrial paleoenvironments. The best example of this application is reconstruction of Toarcian (Early Jurassic) Ocean Anoxic Event associated with volcanism, carbon burial, and species mass extinction. This opens new perspectives for studying oxic, anoxic and euxinic conditions of sedimentary basins in different geologic epochs.

Determinations of thallium concentrations and ${ }^{203} \mathrm{Tl} /{ }^{205} \mathrm{Tl}$ ratios, in geologic and environmental settings, have enabled fingerprinting different pointsource emissions to evaluate relative source strengths, and to better understand spatial and temporal $\mathrm{Tl}$ distribution patterns and geochemical interactions under different physicochemical and biotic conditions. However, a study by Liu et al. (2020) indicated that there might be some implications for fingerprinting some industrial point-source emissions especially when the ${ }^{205} \mathrm{Tl} /{ }^{203} \mathrm{Tl}$ ratios of processing wastes are dramatically different from those of primary raw materials. Besides, there are still very few studies on $\mathrm{Tl}$ isotope fractionation during weathering, soil formation, soil-plant interactions and $\mathrm{Tl}$ translocation in plant species under variable environmental and biological factors.

Open Access This article is licensed under a Creative Commons Attribution 4.0 International License, which permits use, sharing, adaptation, distribution and reproduction in any medium or format, as long as you give appropriate credit to the original author(s) and the source, provide a link to the Creative Commons licence, and indicate if changes were made. The images or other third party material in this article are included in the article's Creative Commons licence, unless indicated otherwise in a credit line to the material. If material is not included in the article's Creative Commons licence and your intended use is not permitted by statutory regulation or exceeds the permitted use, you will need to obtain permission directly from the copyright holder. To view a copy of this licence, visit http://creativecommons.org/licenses/by/4.0/. 


\section{References}

Albers JP, Bain JHC (1985) Regional setting and new information on some critical geologic features of the West Shasta district, California. Econ Geol 80:2072-2091. https://doi.org/10.2113/gsecongeo.80.8.2072

Alderton DHM, Serafimovski T, Mullen B, Fairall K, James S (2005) The chemistry of waters associated with metal mining in Macedonia. Mine Water Environ 24:139-149. https://doi.org/10.1007/s10230-005-0085-z

Aldridge $S$ (2011) The chemistry of the group 13 metals in the + 3 oxidation state: simple inorganic compounds. In: Aldridge S, Downs AJ (eds) The group 13 metals aluminium, gallium, indium and thallium: chemical patterns and peculiarities. Wiley-Blackwell, Chichester, pp 75-147. https://doi.org/10.1002/9780470976548.ch2

Alpers CN, Nordstrom DK, Spitzley J (2003) Extreme acid mine drainage from a pyritic massive sulfide deposit: the Iron Mountain end-member. In: Jambor JL, Blowes DW, Ritchie AIM (eds) Environmental Aspects of Mine Wastes. Mineralogical Association of Canada, Nepean, pp 407-430

Anagboso M, Turner A, Braungardt Ch (2013) Fractionation of thallium in the Tamar estuary, south west England. J Geochem Explor 125:1-7. https://doi.org/10.1016/j. gexplo.2012.10.018

Anderson CWN, Brooks RR, Chiarucci A, LaCoste CJ, Leblanc M, Robinson BH, Simcock R, Teward RB (1999) Phytomining for nickel, thallium and gold. J Geochem Explor 67:407-415. https://doi.org/10.1016/S03756742(99)00055-2

Bačeva K, Stafilov T, Šajn R, Tănăselia C, Makreski P (2014) Distribution of chemical elements in soils and stream sediments in the area of abandoned Sb-As-Tl Allchar mine, Republic of Macedonia. Environ Res 133:7-89. https://doi. org/10.1016/j.envres.2014.03.045

Baker RGA, Rehkämper M, Hinkley TK, Nielsen SG, Toutain JP (2009) Investigation of thallium fluxes from subaerial volcanism - Implications for the present and past mass balance of thallium in the oceans. Geochim Cosmochim Acta 73:6340-6359. https://doi.org/10.1016/j.gca.2009. 07.014

Belzile N, Chen Y-W (2017) Thallium in the environment: a critical review focused on natural waters, soils, sediments and airborne particles. Appl Geochem 84:218-243. https:// doi.org/10.1016/j.apgeochem.2017.06.013

Berg T, Steinnes E (1997) Recent trends in atmospheric deposition of trace elements in Norway as evident from the 1995 moss survey. Sci Total Environ 208:197-206. https://doi. org/10.1016/S0048-9697(97)00253-2

Biagioni C, D’Orazio M, Lepore GO, d'Acapito F, Vezzoni S (2017) Thallium-rich rust scales in drinkable water distribution system: a case study from northern Tuscani, Italy. Sci Total Environ 587/588:491-501. https://doi.org/10. 1016/j.scitotenv.2017.02.177

Biagioni C, D’Orazio M, Vezzoni S, Dini A, Orlandi P (2013) Mobilization of $\mathrm{Tl}-\mathrm{Hg}-\mathrm{As}-\mathrm{Sb}-(\mathrm{Ag}, \mathrm{Cu})-\mathrm{Pb}$ sulfosalt melts during low-grade metamorphism in the Alpi Apuane (Tuscani, Italy). Geology 41:747-750. https://doi.org/10. 1130/G34211.1
Birungi ZS, Chirva EMN (2015) The adsorption potential and recovery of thallium using green micro-algae from eutrophic water sources. J Hazard Mater 299:67-77. https://doi.org/10.1016/j.jhazmat.2015.06.011

Blusztajn J, Nielsen SG (2018) Thallium isotope systematics in volcanic rocks from St. Helena-constraints on the origin of the HIMU reservoir. Chem Geol 476:292-301. https:// doi.org/10.1016/j.chemgeo.2017.11.025

Boev B, Bermanec V, Serafimovski T, Lepitkova S, Mikulcic S, Soufek M, Jovanovski G, Stafilov T, Najdoski M (2001-2002) Allchar mineral assemblage. Geol Maced 15/16:1-23

Bowman CN, Young SA, Kaljo D, Eriksson ME, Them TR, Hints O, Owens JD (2019) Linking the progressive expansion of reducing conditions to a stepwise mass extinction event in the late Silurian oceans. Geology 47(10):968-972. https://doi.org/10.1130/G46571.1

Böning Ph, Schnetger B, Beck M, Brumsack H-J (2018) Thallium dynamics in the southern North Sea. Geochim Cosmochim Acta 227(15):143-155. https://doi.org/10.1016/j. gca.2018.02.024

Byrne RH (2002) Inorganic speciation of dissolved elements in seawater: the influence of $\mathrm{pH}$ on concentration ratios. Geochem T 3:11-16. https://doi.org/10.1039/B109732F

Cabała J, Teper L (2007) Metalliferous constituents of rhizosphere soils contaminated by $\mathrm{Zn}-\mathrm{Pb}$ mining in southern Poland. Water Air Soil Poll 178:351-362. https://doi.org/ 10.1007/s11270-006-9203-1

Campanella B, Onor M, D’Ulivo A, Giannecchini R, D’Orazio M, Petrini R, Bramanti E (2016) Human exposure to thallium through tap water: a study from Valdicastello Carducci and Pietrasanta (northern Tuscani, Italy). Sci Total Environ 548/549:33-42. https://doi.org/10.1016/j. scitotenv.2016.01.010

Campanella B, Casiot C, Onor M, Perotti M, Petrini R, Bramanti E (2017) Thallium release from acid mine drainages: speciation in river and tap water from Valdicastello mining district (northwest Tuscany). Talanta 171:255-261. https:// doi.org/10.1016/j.talanta.2017.05.009

Caritat P de, Reimann C (2017) Publicly available datasets on thallium ( $\mathrm{Tl}$ ) in the environment - a comment on Presence of thallium in the environment: sources of contaminations, distribution and monitoring methods by Bożena Karbowska, Environ Monit Assess (2016) 188, 640 (DOI 10.1007/s10661-016-5647-y). Environ Monit Assess 189, 232:1-11. https://doi.org/10.1007/s10661-017-5945-z

Carson BL, Smith IC (1977) Thallium - an appraisal of environmental exposure. Technical Report. Kansas City Mo: Midwest Research Institute

Casiot C, Egal M, Bruneel O, Verma N, Parmentier M, ElbazPoulichet F (2011) Predominance of aqueous Tl(I) species in the river system downstream from the abandoned Carnoulès mine (Southern France). Environ Sci Technol 45:2056-2064. https://doi.org/10.1021/es102064r

Cheam V (2001) Thallium contamination of water in Canada. Water Qual Res J Can 36:851-877. https://doi.org/10. 2166/wqrj.2001.046

Cheam V, Lechner J, Desrosiers R, Sekerka I (1996) Direct determination of dissolved and total thallium in lake waters by Laser-Excited Atomic Fluorescence Spectrometry. 
J Environ A Ch 63:153-165. https://doi.org/10.1080/ 03067319608026261

Cidu R (2011) Mobility of aqueous contaminants at abandoned mining sites: insights from case studies in Sardinia with implications for remediation. Environ Earth Sci 64(2):503-512. https://doi.org/10.1007/s12665-010-0874$\mathrm{y}$

Cruz-Hernández Y, Ruiz-García M, Villalobos M, Romero FM, Meza-Figueroa D, Garrido F, Hernández-Alvarez E, PiPuig T (2018) Fractionation and mobility of thallium in areas impacted by mining-metallurgical activities: identification of a water-soluble Tl(I) fraction. Environ Pollut 237:154165. https://doi.org/10.1016/j.envpol.2018.02.031

D’Orazio M, Campanella B, Bramanti E, Ghezzi L, Onor M, Vianello G, Vittori-Antisali L, Petrini R (2020) Thallium pollution in water, soils and plants from a past-mining site of Tuscany: sources, transfer processes and toxicity. J Geochem Explor 209:106434. https://doi.org/10.1016/j. gexplo.2019.106434

Davies M, Figueroa L, Wildeman T, Bucknam Ch (2016) The oxidative precipitation of thallium at alkaline $\mathrm{pH}$ for treatment of mining influenced water. Mine Water Environ 35:77-85. https://doi.org/10.1007/s10230-015-0349-1

Deditius AP, Reich M (2016) Constraints on the solid solubility of $\mathrm{Hg}, \mathrm{Tl}$, and $\mathrm{Cd}$ in arsenian pyrite. Am Mineral 101:1451-1459. https://doi.org/10.2138/am-2016-5603

DelValls TA, Sáenz V, Arias AM, Blasco J (1999) Thallium in the marine environment: first ecotoxicological assessments in the Guadalquivir estuary and its potential adverse effect on the Doñana European natural reserve after the Aznalcollar mining spill. Cienc Mar 25(2):161-175

Di Candia D, Biehler-Gomez L, GiordanovG, Cattaneo C (2020) A case of thallium intoxication by walking in a field. Forensic Sci Int 2:100102. https://doi.org/10.1016/j.fsir. 2020.100102

Dinelli E, Lima A, Albanese S, Birke M, Cicchella D, Giaccio L, Valera P, De Vivo B (2012) Major and trace elements in tap water from Italy. J Geochem Explor 112:54-75. https://doi. org/10.1016/j.gexplo.2011.07.009

Dmowski K, Kozakiewicz A, Kozakiewicz M (1998) Small mammal populations and community under conditions of extremely high thallium contamination in the environment. Ecotox Environ Safe 41:2-7. https://doi.org/10.1006/eesa. 1998.1660

Dunn CE, Erdman JA, Hall G, Smith SC (1992) Biogeochemical Exploration Simplified. Notes for a short course on methods of biogeochemical and geobotanical prospectingwith emphasis on arid terrains. Assn Expl Geoch

Enghag P (2004) Encyclopedia of elements. WILEY-VCH Verlag GmbH \& Co KGaA, Weinheim

Fan H, Nielsen SG, Owens JD, Auro M, Shu Y, Hardisty DS, Horner TJ, Bowman CN, Young SA, Wen H (2020) Constraining oceanic oxygenation during the Shuram excursion in South China using thallium isotopes. Geobiology 18:348-365. https://doi.org/10.1111/gbi.12379

Ferronato C, Carbone S, Vianello G, Antisari LV (2016) Thallium toxicity in Mediterranean horticultural crops (Fragaria vesca L., Mentha pulegium L., Ocimum basilicum L.). Water Air Soil Poll 227(375):1-10. https://doi.org/10. 1007/s11270-016-3027-4
Fortescue JAC (1992) Landscape geochemistry-retrospect and prospect-1990. Appl Geochem 7:1-53. https://doi.org/ 10.1016/0883-2927(92)90012-R

Gao Y, Leermakers M, Elskens M, Billon G, Ouddane B, Fischer JC, Baeyens W (2007) High resolution profiles of thallium, manganese and iron assessed by DET and DGT techniques in riverine sediment pore waters. Sci Total Environ 373:526-533. https://doi.org/10.1016/j.scitotenv. 2006.11.047

George L (2013) Trace and minor elements in galena: a reconnaissance LA-ICP-MS study. Thesis submitted to an Honours Degree in Geology. Adelaide: The University of Adelaide

Goldschmidt VM (1954) Geochemistry. Oxford Univ. Press, New York

Gołębiowska B, Rzepa G, Pieczka A (2017) Exceptional Tlbearing manganese oxides from Zalas, Krakow area, southern Poland. Mineralogia 46(1-2):3-18. https://doi. org/10.1515/mipo-2016-0002

Gomez-Gonzalez MA, Garcia-Guinea J, Laborda F, Garrido F (2015) Thallium occurrence and partitioning in soils and sediments affected by mining activities in Madrid province (Spain). Sci Total Environ 536:268-278. https://doi.org/ 10.1016/j.scitotenv.2015.07.033

Graham GE, Kelley KD (2009) The Drenchwater deposit, Alaska: an example of a natural low $\mathrm{pH}$ environment resulting from weathering of an undisturbed shale-hosted $\mathrm{Zn}-\mathrm{Pb}-\mathrm{Ag}$ deposit. Appl Geochem 24:232-245. https:// doi.org/10.1016/j.apgeochem.2008.11.016

Greaney AT, Rudnick RL, Helz RT, Gaschnig RM, Piccoli PM, Ash RD (2017) The behavior of chalcophile elements during magmatic differentiation as observed in Kilauea Iki lava lake, Hawaii. Geochim Cosmochim Ac 210(1):71-96. https://doi.org/10.1016/j.gca.2017.04.033

Grimalt JO, Ferrer M, Macpherson E (1999) The mine tailing accident in Aznalcollar. Sci Total Environ 242:3-11. https://doi.org/10.1016/S0048-9697(99)00372-1

Grösslova Z, Vaněk A, Óborná V, Mihaljevič M, Ettler V, Trubač J, Drahota P, Penížek V, Pavlů L, Sracek O, Kŕíbek B, Voegelin A, Göttlicher J, Drábek O, Tejnecký V, Houška J, Mapani B, Zádorová T (2018) Thallium contamination of desert soil in Namibia: chemical, mineralogical and isotopic insights. Environ Pollut 239:272-280. https://doi.org/10.1016/j.envpol.2018.04.006

Haiduc I, Zuckerman JJ (2011) Basic organometallic chemistry: containing comprehensive bibliography. Walter de Gruyter, Berlin

Håkanson L (1980) An ecological risk index for aquatic pollution control. A sedimentological approach. Water Res 14:975-1001. https://doi.org/10.1016/00431354(80)90143-8

He Y, Men B, Yang X, Wang D (2015) Bioturbation/bioirrigation effect on thallium released from reservoir sediment by different organism types. Sci Total Environ 532:617-624. https://doi.org/10.1016/j.scitotenv.2015.06. 075

Heim M, Wappelhorst O, Markert B (2002) Thallium in terrestrial environments-occurrence and effects. Ecotoxicology 11:369-377. https://doi.org/10.1023/A: 1020513523462 
Herrmann J, Voegelin A, Palatinus L, Mandold S, Majzlan J (2018) Secondary Fe-As-Tl mineralization in soils near Buus in the Swiss Jura Mountains. Eur $\mathbf{J}$ Mineral 30:887-898. https://doi.org/10.1127/ejm/2018/0030-2766

Hettmann K, Marks MAW, Kreissig K, Zack T, Wenzel T, Rehkämper, Jacob DE, Markl G (2014) The geochemistry of $\mathrm{Tl}$ and its isotopes during magmatic and hydrothermal processes: the peralkaline Ilimaussaq complex, southwest Greenland. Chem Geol 366:1-13. https://doi.org/10.1016/ j.chemgeo.2013.12.004

Holubík O, Vaněk A, Mihaljevič M, Vejvodová K (2020) Higher Tl bioaccessibility in white mustard (hyper-accumulator) grown under the soil than hydroponic conditions: a key factor for the phytoextraction use. J Environ Manag 255:109880. https://doi.org/10.1016/j.jenvman.2019. 109880

Howarth S, Prytulak J, Little SH, Hammond SJ, Widdowson M et al (2018) Thallium concentration and thallium isotope composition of lateritic terrains. Geochim Cosmochim Acta 239(15):446-462. https://doi.org/10.1016/j.gca.2018. 04.017

Huber F, Kirchmann H (1978) Biomethylation of Tl(I) compounds. Inorg Chim Acta 29:249-250

Jacobson AR, McBride MB, Baveye P, Steenhuis TS (2005) Environmental factors determining the trace-level sorption of silver and thallium to soils. Sci Total Environ 345:191-205. https://doi.org/10.1016/j.scitotenv.2004.10. 027

Jakubowska M, Pasieczna A, Zembrzuski W, Świt Z, Łukaszewski Z (2007) Thallium in fractions of soil formed on floodplain terraces. Chemosphere 66(4):611-618. https://doi.org/10.1016/j.chemosphere.2006.07.098

Jakubowska M, Zembrzuski W, Łukaszewski Z (2008) Thallium determination at the single picomole per liter level by flow-injection differential-pulse anodic stripping voltammetry. Electroanalysis 20:1073-1077. https://doi.org/10. 1002/elan.201000151

Jardine TD, Doig LE, Jones PD, Bharadwaj L, Carr M, Tendler B, Lindenschmidt KE (2019) Vanadium and thallium exhibit biodilution in a northern river food web. Chemosphere 233:381-386. https://doi.org/10.1016/j. chemosphere.2019.05.282

Jones C, Stasch A (2011) The chemistry of the group 13 metals in the +1 oxidation state. In: Aldridge S, Downs AJ (eds) The group 13 metals aluminium, gallium, indium and thallium: chemical patterns and peculiarities. WileyBlackwell, Chichester, pp 285-341

Jović V (1993) Thallium in rocks, soils, plants: past progress and future needs. N Jb Miner Abh 166:43-52

Kabata-Pendias A, Pendias H (2011) Trace elements in soils and plants. CRC Press, Boca Raton

Kabata-Pendias A, Szteke B (2015) Trace elements in abiotic and biotic environments. CRC Press, Boca Raton

Karbowska B (2016) Presence of thallium in the environment: sources of contaminations, distribution and monitoring methods. Environ Monit Assess 188:640. https://doi.org/ 10.1007/s10661-016-5647-y

Karlsson U, Karlsson S, Düker A (2006) The effect of light and iron(II)/iron(III) on the distribution of Tl(I)/Tl(III) in fresh water systems. J Environ Monit 8:634-640. https://doi.org/ $10.1039 / \mathrm{b} 516445 \mathrm{a}$
Kazantzis G (2000) Thallium in the environment and health effects. Environ Geochem Hlth 22:275-280. https://doi. org/10.1023/A:1006791514080

Kellerhals T, Tobler L, Brütsch S, Sigi M, Wacker L, Gäggeler HW, Schwikowski M (2010) Thallium as a tracer for preindustrial volcanic eruptions in an ice core record from Illimani, Bolivia. Environ Sci Technol 44:888-893. https:// doi.org/10.1021/es902492n

Kersten M, Xiao T, Kreissig K, Brett A, Coles BJ, Rehkämper M (2014) Tracing anthropogenic thallium in soil using stable isotope compositions. Environ Sci Technol 48:9030-9036. https://doi.org/10.1021/es501968d

Kicińska A (2009) Arsenic and thallium in soils and plants of the Bukowno area. Ochrona Środowiska i Zasobów Naturalnych 40:199-208 (in Polish)

Koljonen T (ed) (1992) Geochemical atlas of Finland, Part: Till. Geological Survey of Finland, Espoo

Knöller K, Fauville A, Mayer B, Strauch G, Friese K, Veizer J (2004) Sulfur cycling in an acid mining lake and its vicinity in Lusatia, Germany. Chem Geol 204:303-323. https://doi. org/10.1016/j.chemgeo.2003.11.009

Krachler M, Zheng J, Fisher D, Shotyk W (2008) Atmospheric inputs of $\mathrm{Ag}$ and $\mathrm{Tl}$ to the Arctic: comparison of a high resolution snow pit (AD 1994-2004) with a firn (AD 1860-1996) and an ice core (previous 16,000 years). Sci Total Environ 399:78-89. https://doi.org/10.1016/j. scitotenv.2008.03.006

Krasnodębska-Ostręga B, Sadowska M, Ostrowska S (2012) Thallium speciation in plant tissues-Tl(III) found in $\mathrm{Si}$ napis alba L. grown in soil polluted with tailing sediment containing thallium minerals. Talanta 93:326-329. https:// doi.org/10.1016/j.talanta.2012.02.042

Laforte L, Tessier A, Gobeil C, Carignan R (2005) Thallium diagenesis in lacustrine sediments. Geochim Cosmochim Acta 69(22):5295-5306. https://doi.org/10.1016/j.gca. 2005.06.006

Law S, Turner A (2011) Thallium in the hydrosphere of south west England. Environ Pollut 159:3484-3489. https://doi. org/10.1016/j.envpol.2011.08.029

Leblanc M, Robinson BH, Petit D, Deram A, Brooks RR (1999) The phytomining and environmental significance of hyperaccumulation of thallium by Iberis intermedia from southern France. Econ Geol 94:109-114. https://doi.org/ 10.2113/gsecongeo.94.1.109

Levinson AA (1980) Introduction to exploration geochemistry, 2nd edn. Applied Publishing Ltd., Wilmette

Li Y, Peng Y, Ma Y, Hu Q, Yang G (2009) Solid phase extraction and flame atomic absorption spectrometry for the determination of trace of thallium. Asian J Chem 21(6):4593-4598

Lin TS, Nriagu J (1999) Thallium speciation in the Great Lakes. Environ Sci Technol 33:3394-3397. https://doi.org/10. 1021/es9810960

Liu J, Luo X, Sun Y, Tsang DCW, Qi J, Zhang W, Li N, Yin M, Wang J, Lippold H, Chen Y, Sheng G (2019a) Thallium pollution in China and removal technologies for waters: a review. Environ Int 126:771-790. https://doi.org/10.1016/ j.envint.2019.01.076

Liu J, Yin M, Zhang W, Tsang DCW, Wei X, Zhou Y, Xiao T, Wang J, Dong X, Sun Y, Chen Y, Li H, Hou L (2019b) Response of microbial communities and interactions to 
thallium in contaminated sediments near a pyrite mining area. Environ Pollut 248:916-928. https://doi.org/10.1016/ j.envpol.2019.02.089

Liu J, Yin M, Xiao T, Zang C, Tsang DCW, Bao Z, Zhou Y, Chen Y, Luo X, Yuan W, Wang Y (2020) Thallium isotopic fractionation in industrial process of pyrite smelting and environmental implications. J Hazard Mater 384:121378. https://doi.org/10.1016/j.jhazmat.1219. 121378

Liu Y, Wang Q, Zhuang W, Yuan Y, Yuan Y, Jiao K, Wang M, Chen Q (2018) Calculation of thallium's toxicity coefficient in the evaluation of potential ecological risk index: a case study. Chemosphere 194:562-569. https://doi.org/10. 1016/j.chemosphere.2017.12.002

López Antón MA, Spears DA, Díaz-Smoano M, Diaz L, Martínez-Tarazona MR (2013) Thallium in coal: analysis and environmental implications. Fuel 105:13-18. https://doi. org/10.1016/j.fuel.2012.08.004

Łukaszewski Z, Karbowska B, Zembrzuski B, Siepak M (2012) Thallium in fractions of sediments formed during the 2004-tsunami in Thailand. Ecotox Environ Safe 80:184-189. https://doi.org/10.1016/j.ecoenv.2012.02.026

Mathis BJ, Kevern NR (1975) Distribution of mercury, cadmium, lead and thallium in a eutrophic lake. Hydrobiologia 42(2-3):133-146. https://doi.org/10.1007/BF00043141

Matthews AD, Riley JP (1970) The occurrence of thallium in sea water and marine sediments. Chem Geol 6:149-152. https://doi.org/10.1016/0009-2541(70)90013-6

Maya-López M, Mireles-Garcia MV, Ramirez-Toledo M, Colin-González AL, Galván-Arzate S, Túnez I, Santamaria A (2018) Thallium-Induced Toxicity in Rat Brain Crude Synaptosomal/Mitochondrial Fractions is Sensitive to Anti-excitatory and Antioxidant Agents. Neurotox Res 33(3):634-640. https://doi.org/10.1007/s12640-017-98631

Migaszewski ZM, Gałuszka A (2019) The origin of pyrite mineralization: implications for Late Cambrian geology of the Holy Cross Mountains (south-central Poland). Sedim Geol 390:45-61. https://doi.org/10.1016/j.sedgeo.2019.07. 004

Migaszewski ZM, Gałuszka A, Dołęgowska S (2018) Arsenic in the Wiśniówka acid mine drainage area (south-central Poland)—mineralogy, hydrogeochemistry, remediation. Chem Geol 493:491-503. https://doi.org/10.1016/j. chemgeo.2018.06.027

Migaszewski ZM, Gałuszka A, Dołęgowska S (2019) Extreme enrichment of arsenic and rare earth elements in acid mine drainage: case study of Wiśniówka mining area (southcentral Poland). Environ Pollut 244:898-906. https://doi. org/10.1016/j.envpol.2018.10.106

Murciego AM, Ayuso EA, Sánchez AG. Pascual EP (2010) The occurrence of $\mathrm{Cd}$ and $\mathrm{Tl}$ in the sphalerite from El Losar del Barco Mine (Ávila, Spain): a potential environmental hazard. Revista de la SEM 13:163-164

Nielsen SG, Goff M, Hesselbo SP, Jenkyns HC, LaRowe DE. Lee C-TA (2011) Thallium isotopes in early diagenetic pyrite-a paleoredox proxy? Geochim Cosmochim Acta 75:6690-6704. https://doi.org/10.1016/j.gca.2011.07.047

Nielsen SG, Mar-Gerrison S, Gannoun A, LaRowe D, Klemm V, Halliday AN, Burton KW, Hein JR (2009) Thallium isotope evidence for a permanent increase in marine organic carbon export in the early Eocene. Earth Planet Sci Lett 278:297-307. https://doi.org/10.1016/j.eps1.2008.12. 010

Nielsen SG, Prytulak J, Blusztajn J, Shu Y, Auro M, Regelous M, Walker J (2017) Thallium isotopes as tracers of recycled materials in subduction zones: review and new data for lavas from Tonga-Kermadec and Central America. J Volcanol Geoth Res 339:23-40. https://doi.org/10.1016/j. jvolgeores.2017.04.024

Nielsen SG, Rehkämper M (2011) Thallium isotopes and their application to problems in earth and environmental science. In: Baskaran M (ed) Handbook of Environmental Isotope Geochemistry. Springer Verlag, Berlin-Heidelberg, pp 247-270

Nielsen SG, Rehkämper M, Baker J, Halliday AN (2004) The precise and accurate determination of thallium isotope compositions and concentrations for water samples by MCICPMS. Chem Geol 204(1-2):109-124. https://doi.org/10. 1016/j.chemgeo.2003.11.006

Nielsen SG, Rehkämper M, Porcelli D, Andersson P, Halliday AN, Swarzenski PW, Latkoczy Ch, Günther D (2005) Thallium isotope composition of the upper continental crust and rivers - an investigation of the continental sources of dissolved marine thallium. Geochim Cosmochim Acta 19(8):2007-2019. https://doi.org/10.1016/j.gca.2004. 10.025

Nielsen SG, Rehkämper M, Teagle DAH, Alt JC, Butterfield D, Halliday AN (2006) Hydrothermal fluid fluxes calculated from the isotopic mass balance of thallium in the ocean crust. Earth Planet Sci Lett 251:120-133. https://doi.org/ 10.1016/j.eps1.2006.09.002

Nordstrom DK (2011a) Hydrogeochemical processes governing the origin, transport and fate of major and trace elements from mine wastes and mineralized rock to surface waters. Appl Geochem 26:1777-1791. https://doi.org/10.1016/j. apgeochem.2011.06.002

Nordstrom DK (2011b) Mine waters: acidic to circumneutral. Elements 7:393-398. https://doi.org/10.2113/gselements. 7.6.393

Nriagu JO (1998) History, production, and uses of thallium. In: Nriagu JO (ed) Thallium in the Environment. John Wiley and Sons, New York, pp 1-14

Nygård T, Steinnes E, Røyset O (2012) Distribution of 23 elements in organic surface soils: contribution from atmospheric transport of pollutants and natural sources. Water Air Soil Poll 223:699-713. https://doi.org/10.1007/ s11270-011-0895-5

Osorio-Rico L, Santamaria A, Galván-Arzate S (2017) Thallium toxicity: general issues, neurological symptoms, and neurotoxic mechanisms. Adv Neurobiol 18:345-353. https:// doi.org/10.1007/978-3-319-60189-2_17

Ostrander CM, Nielsen SG, Owens JD, Kendall B, Gordon GW, Romaniello SJ, Anbar AD (2019) Fully oxygenated water columns over continental shelves before the Great Oxidation Event. Nat Geosci 12:186-191. https://doi.org/10. 1038/s41561-019-0309-7

Owens JD, Nielsen SG, Horner TJ, Ostrander CM, Peterson LC (2017) Thallium-isotopic compositions of euxinic sediments as a proxy for global manganese-oxide burial. Geochim Cosmochim Acta 213:291-307. https://doi.org/ 10.1016/j.gca.2017.06.041 
Paulo A, Lis J, Pasieczna A (2002) Thallium at the end of the 20th century. Przegląd Geologiczny 5:403-407 (in Polish)

Peacock CL, Moon EM (2012) Oxidative scavenging of thallium by birnessite: explanation for thallium enrichments and stable isotope fractionation in marine ferromanganese precipitates. Geochim Cosmochim Acta 84:297-313. https://doi.org/10.1016/j.gca.2012.01.036

Perotti M, Petrini R, D’Orazio M, Ghezzi L, Giannecchini R, Vezzoni S (2018) Thallium and other potentially toxic elements in the Baccatoio stream catchment (Northern Tuscany, Italy) receiving drainages from abandoned mines. Mine Water Environ 37:431-441. https://doi.org/10.1007/ s10230-017-0485-x

Peter ALJ, Viraraghavan T (2005) Thallium: a review of public health and environmental concerns. Environ Int 31:493-501. https://doi.org/10.1016/j.envint.2004.09.003

Peña-Fernández A, González-Muñoz MJ, Lobo-Bedmar MC (2014) Establishing the importance of human health risk assessment for metals and metalloids in urban environments. Environ Int 72:176-185. https://doi.org/10.1016/j. envint.2014.04.007

Petrini R, Cidu R, Slejko FF (2016) Thallium contamination in the Raibl mine site stream drainage system (eastern Alps, Italy). Mine Water Environ 35:55-63. https://doi.org/10. 1007/s10230-015-0346-4

Qi W, Chen Y, Cao J (1992) Indium and thallium background contents in soils in China. Int J Environ Stud 40:311-315. https://doi.org/10.1080/00207239208710737

Quisefit JP, Toutain JP, Bergametti G, Javoy M, Cheynet B, Person A (1989) Evolution versus cooling of gaseous volcanic emissions from Momotombo Volcano, Nicaragua: thermochemical model and observations. Geochim Cosmochim Acta 53(10):2591-2608. https://doi.org/10. 1016/0016-7037(89)90131-2

Rader ST, Mazdab FK, Barton MD (2018) Mineralogical thallium geochemistry and isotope variations from igneous, metamorphic, and metasomatic systems. Geochim Cosmochim Acta 243(15):42-65. https://doi.org/10.1016/j. gca.2018.09.019

Rader ST, Maier RM, Barton MD, Mazdab FK (2019) Uptake and fractionation of thallium by Brassica juncea in a geogenic thallium-amended substrate. Environ Sci Technol 53(5):2441-2449. https://doi.org/10.1021/acs.est.8b06222

Rasool A, Nasim W, Xiao T, Ali W, Shafeeque M, Sultana SR, Fahad S, Munis MFH, Chaudhary HJ (2020) Microbial diversity response in thallium polluted riverbank soils of the Lanmuchang. Ecotox Environ Safe 187:109854. https://doi.org/10.1016/j.ecoenv.2019.109854

Rehkämper M, Frank M, Hein JR, Porcelli D, Halliday A, Ingri J, Libetrau V (2002) Thallium isotope variations in seawater and hydrogenetic, diagenetic and hydrothermal ferromanganese deposits. Earth Planet Sci Lett 197:65-81. https://doi.org/10.1016/S0012-821X(02)00462-4

Rehkämper M, Halliday AN (1999) The precise measurement of $\mathrm{Tl}$ isotopic compositions by MC-ICPMS: application to the analysis of geological materials and meteorites. Geochim Cosmochim Ac 63:935-944. https://doi.org/10.1016/ S0016-7037(98)00312-3

Rehkämper M, Nielsen SG (2004) The mass balance of dissolved thallium in the oceans. Mar Chem 85:125-139. https://doi.org/10.1016/j.marchem.2003.09.006
Reimann C, Caritat P de (1998) Chemical elements in the environment. factsheets for geochemist and environmental scientist. Springer, Berlin

Reimann C, Finne TE, Nordgulen Ø, Saether OM, Arnoldussen A, Banks D (2009) The influence of geology and land-use on inorganic stream water quality in the Oslo region. Aquat Geochem 24:1862-1874. https://doi.org/10.1016/j. apgeochem.2009.06.007

Renkema H, Koopmans A, Hale B, Berkelaar E (2014) Thallium and potassium uptake kinetics and competition differ between durum wheat and canola. Environ Sci Pollut R 22:2166-2174. https://doi.org/10.1007/s11356-014-34907

Rickwood PC (1983) Crustal abundance, distribution, and crystal chemistry of the elements. In: Govett GJS (ed) Handbook of Exploration Geochemistry, 3, Rock Geochemistry in Mineral Exploration. Elsevier Scientific Publishing Co., Amsterdam, pp 347-387

Rickwood CJ, King M, Huntsman-Mapila S (2015) Assessing the fate and toxicity of thallium I and thallium III to three aquatic organisms. Ecotoxicol Environ Saf 115:300-308. https://doi.org/10.1016/j.ecoenv.2014.12.024

Robinson B, Anderson C (2018) Element case studies: thallium and noble metals. In: Van der Ent A, Echevarria G, Baker AJ, Morel JL (eds) Agromining: farming for metals. Springer, Cham, pp 253-261

Romero FM, Prol-Ledesma RM, Canet C, Alvares LN, PérezVázquez R (2010) Acid drainage at the inactive Santa Lucia mine, western Cuba: natural attenuation of arsenic, barium and lead, and geochemical behavior of rare earth elements. Appl Geochem 25:716-727. https://doi.org/10. 1016/j.apgeochem.2010.02.004

Rühling $\AA$, Tyler G (2004) Changes in the atmospheric deposition of minor and rare elements between 1975 and 2000 in south Sweden, as measured by moss analysis. Environ Pollut 131:417-423. https://doi.org/10.1016/j.envpol. 2004.03.005

Salminen R (ed) (2005) Geological Atlas of Europe. Part 1. Background Information, Methodology and Maps. Geological Survey of Finland, Espoo

Sánchez-Chardi A (2007) Tissue, age, and sex distribution of thallium in shrews from Doñana, a protected area in SW Spain. Sci Total Environ 383:237-240. https://doi.org/10. 1016/j.scitotenv.2007.05.017

Schaub G (1996) Thallium-Environmental Health Criteria. International Programme on Chemical Safety, World Health Organization Publication. http://www.inchem.org/ documents/ehc/ehc/ehc182.htm

Schedlbauer OF, Heumann KG (2000) Biomethylation of thallium by bacteria and first determination of biogenic dimethylthallium in the ocean. Appl Organomet Chem 14:330-340. https:// doi.org/10.1002/(SICI)1099-0739(200006)

Shacklette HT, Erdman JA, Harms TF, Papp CSE (1978) Trace elements in plant foodstuffs. In: Oehme FW (ed) Toxicity of heavy metals in the environment. Marcel Dekker Inc, New York, pp 25-68

Shotyk W, Bicalho B, Cuss CW, Grant-Weaver I, Nagel A, Noernberg T, Poesch M, Sinnatamby NR (2019) Bioaccumulation of $\mathrm{Tl}$ in otoliths of Trout-perch (Percopsis omiscomaycus) from the Athabasca River, upstream and downstream of bitumen mining and upgrading. Sci Total 
Environ 650:2559-2566. https://doi.org/10.1016/j. scitotenv.2018.09.318

Shu Y, Nielsen SG, Zeng Z, Shinjo R, Blusztajn J, Wang X, Chen S (2017) Tracing subducted sediment inputs to the Ryukyu arc-Okinawa Trough system: evidence from thallium isotopes. Geochim Cosmochim Acta 217:462-491. https://doi.org/10.1016/j.gca.2017.08.035

Smith IC, Carson BL (1977) Trace Metals in the Environment: vol 1-Thallium. Ann Arbor Publishers, Inc., Michigan

Smith DB, Cannon WF, Woodruff LG, Ellefsen KJ (2014) Geochemical and mineralogical maps for soils of the conterminous United States. United States Geological Survey Open-File Report:2014-1082. U.S. Geological Survey, Reston

Spencer ER, Peterson R, Madrid R, Raine CS (1973) Effects of thallium salts on neuronal mitochondria in organotype cord-ganglia-muscle combination cultures. J Cell Biol 58:79-95. https://doi.org/10.1083/jcb.58.1.79

Sucharová J, Suchara I (2004) Current multi-element distribution in forest epigeic moss in the Czech Republic-a survey of the Czech national biomonitoring programme 2000. Chemosphere 57:1389-1398. https://doi.org/10.1016/j. chemosphere.2004.08.016

Suchara I, Sucharová J, Hola M, Reimann C, Boyd R, Filzmoser P, Englmaier P (2011) The performance of moss, grass and 1- and 2-year old spruce needles as bioindicators of contamination: a comparative study at the scale of the Czech Republic. Sci Total Environ 409(11):2281-2297. https:// doi.org/10.1016/j.scitotenv.2011.02.003

Sun J, Zou X, Ning Z, Sun M, Peng J, Xiao T (2012) Culturable microbial groups and thallium-tolerant fungi in soils with high thallium contamination. Sci Total Environ 441:258-264. https://doi.org/10.1016/j.scitotenv.2012.09. 053

Tatsi K, Turner A (2014) Distributions and concentrations of thallium in surface waters of a region impacted by historical metal mining (Cornwall, UK). Sci Total Environ 473-474:139-146. https://doi.org/10.1016/j.scitotenv. 2013.12.003

Them IITR, Gill BC, Caruthers AH, Gerhardt AM, Gröcke DR, Lyons TW, Marroquin SM, Nielsen SG, Trabucho Alexandre J, Owens JD (2018) Thallium isotopes reveal protracted anoxia during the Toarcian (Early Jurassic) associated with volcanism, carbon burial, and mass extinction. Proc Natl Acad Sci 115(26):6596-6601. https:// doi.org/10.1073/pnas.1803478115

Tremel A, Masson P, Sterckeman T, Baize D, Mench M (1997) Thallium in French agrosystems-1. Thallium contents in arable soils. Environ Pollut 95:293-302. https://doi.org/10. 1016/S0269-7491(96)00145-5

Turner A, Cabon A, Glegg GA, Fisher AS (2010) Sedimentwater interactions of thallium under simulated estuarine conditions. Geochim Cosmochim Acta 74:6779-6787. https://doi.org/10.1016/j.gca.2010.09.004

Twidwell LG, Williams-Beam C (2002) Potential technologies for removing thallium from mine and process wastewater: an abbreviated annotation of literature. Eur $\mathbf{J}$ Mineral Process Environ Protect 2(1):1-10

US EPA (US Environmental Protection Agency) (2003) National primary drinking water regulations. http://water. epa.gov/safewater/dwh/t-ioc/thallium/html
USGS (US Geological Survey) (2019) Mineral Commodity. Summaries 2019. http://minerals.usgs.gov/minerals/pubs/ commodity/thallium

Van der Ent A, Baker AJM, Reeves RD, Pollard AJ, Schat H (2013) Hyperaccumulators of metal and metalloid trace elements: facts and fiction. Plant Soil 362:319-334. https:// doi.org/10.1007/s11104-012-1287-3

Vaněk A, Chrastný V, Mihaljevič M, Drahota P, Grygar T, Komárek M (2009) Lithogenic thallium behavior in soils with different land use. J Geochem Explor 102:7-12. https://doi.org/10.1016/j.gexplo.2008.10.004

Vaněk A, Grösslova Z, Mihaljevič M, Ettler V, Chrastný V, Komárek M, Tejnecký V, Drábek O, Penížek V, Galušková I, Vaněčková B, Pavlů L, Ash C (2015) Thallium contamination of soils/vegetation as affected by sphalerite weathering: a model rhizospheric experiment. J Hazard Mater 283:148-156. https://doi.org/10.1016/j.jhazmat. 2014.09.018

Vaněk A, Grösslova Z, Mihaljevič M, Ettler V, Trubač J, Chrastný V, Penížek V, Teper L, Cabała J, Voegelin A, Zádorová T, Oborná V, Drábek O, Holubík O, Houška J, Pavlů L, Ash C (2018) Thallium isotopes in metallurgical wastes/contaminated soils: a novel tool to trace metal source and behavior. J Hazard Mater 343:78-85. https:// doi.org/10.1016/j.jhazmat.2017.09.020

Vaněk A, Grösslova Z, Mihaljevič M, Trubač J, Ettler V, Teper L, Cabała J, Rohovec J, Zádorová T, Penížek V, Pavlů L, Holubík O, Něměcek K, Houška J, Drábek O, Ash C (2016) Isotopic tracing of thallium contamination in soils affected by emissions from coal-fired power plants. Environ Sci Technol 50:9864-9871. https://doi.org/10.1021/acs.est. 6b01751

Vaněk A, Komárek M, Vokurková P, Mihaljevič M, Šebek O, Panušková G, Chrastný V, Drábek O (2011) Effect of illite and birnessite on thallium retention bioavailability in contaminated soil. J Hazard Mater 191:170-176. https:// doi.org/10.1016/j.jhazmat.2011.04.065

Vaněk A, Komárek M, Chrastný V, Galušková I, Mihaljevič M, Šebek O, Drahota P, Tejnecký V, Vokurková P (2012) Effect of low-molecular-weight organic acids on the leaching of thallium and accompanying cations from soila model rhizosphere solution approach. J Geochem Explor 112:212-217. https://doi.org/10.1016/j.gexplo.2011.08. 010

Vaněk A, Mihaljevič M, Galušková I, Chrastný V, Komárek M, Penížek V, Zádorová T, Drábek O (2013) Phase-dependent phytovailability of thallium-a synthetic soil experiment. J Hazard Mater 250/251:265-271. https://doi.org/10.1016/ j.jhazmat.2013.01.076

Vaněk A, Voegelin A, Mihaljevič M, Ettler V, Trubač J, Drahota P, Vaňková M, Oborná V, Vejvodová K, Penížek V, Pavlů L, Drábek O, Vokurková P, Zádorová T, Holubík O (2020) Thallium stable isotope ratios in naturally Tl-rich soils. Geoderma 364(1):114183. https://doi.org/10.1016/j. geoderma.2020.114183

Viets J, Leach D, Lichte F, Hopkins R, Gent C, Powell J (1996) Paragenetic and minor- and trace-element studies of Mississippi Valley-type ore deposits of the Silesian-Cracow district, Poland. Prace InstGeol 154:51-71

Wedepohl KH (1972) Handbook of Geochemistry. SpringerVerlag, Berlin 
Wedepohl KH (1995) The composition of continental crust. Geochim Cosmochim Acta 59(7):1217-1232. https://doi. org/10.1016/0016-7037(95)00038-2

Wick S, Baeyens B, Fernandez MM, Voegelin A (2018) Thallium Adsorption onto illite. Environ Sci Technol 752(2):571-580. https://doi.org/10.1021/acs.est.7b04485

Wojtkowiak T, Karbowska B, Zembrzuski W, Siepak M, Łukaszewski Z (2016) Miocene colored waters: a new significant source of thallium in the environment. J Geochem Explor 161:42-48. https://doi.org/10.1016/j. gexplo.2015.09.014

Xiao TF, Boyle D, Guha J, Rouleau A, Hong YT, Zheng BS (2003) Groundwater-related thallium transfer processes and their impact on the ecosystem: southwest Guizhou Province, China. Appl Geochem 18:675-691. https://doi. org/10.1016/S0883-2927(02)00154-3

Xiao T, Guha J, Boyle D, Liu CQ, Chen J (2004a) Environmental concerns related to high thallium levels in soils and thallium uptake by plants in southwest Guizhou, China. Sci Total Environ 318:223-244. https://doi.org/10.1016/ S0048-9697(03)00448-0

Xiao T, Guha J, Boyle D, Liu CQ, Zheng B, Wilson GC, Rouleau A, Chen J (2004b) Naturally occurring thallium: a hidden geoenvironmental health hazard? Environ Int 30:501-507. https://doi.org/10.1016/j.envint.2003.10.004

Xiao T, Yang F, Shehong L, Zheng B, Ning Z (2012) Thallium pollution in China: a geo-environmental perspective. Sci Total Environ 421-422:51-58. https://doi.org/10.1016/j. scitotenv.2011.04.008

Xiong Y (2007) Hydrothermal thallium mineralization up to $300^{\circ} \mathrm{C}$ : a thermodynamic approach. Ore Geol Rev 32:291-313. https://doi.org/10.1016/j.oregeorev.2006.10. 003
Xu H, Luo Y, Wang P, Zhu J, Yang Z, Liu Z (2019) Removal of thallium in water/wastewater: a review. Water Res 165:114981. https://doi.org/10.1016/j.watres.2019.114981

Zhang Q, Rickaby REM (2020) Interactions of thallium with marine phytoplankton. Geochim Cosmochim Acta 276:1-13. https://doi.org/10.1016/j.gca.2020.02.024

Zhang H, Li M, Yang Z, Sun Y, Yan J, Chen D, Chen Y (2017) Isolation of a non-traditional sulfate reducing-bacteria Citrobacter freundii sp. and bioremoval of thallium and sulfate. Ecol Eng 102:397-403. https://doi.org/10.1016/j. ecoleng.2017.02.049

Zhang Z, Zhang B, Long J, Zhang X, Chen G (1998) Thallium pollution associated with mining of thallium deposits. Sci China Ser D 41(1):75-81. https://doi.org/10.1007/ BF02932424

Zhou T, Fan Y, Yuan F, Cooke D, Zhang X, Li L (2008) A preliminary investigation and evaluation of the thallium environmental impacts of the unmined Xiangquan thallium-only deposit in Hexian, China. Environ Geol 54:131-145. https://doi.org/10.1007/s00254-007-0800-0

Zhuang W, Gao X (2015) Distribution, enrichment and sources of thallium in the surface sediments of the southwestern coastal Laizhou Bay, Bohai Sea. Mar Pollut Bull 96:502-507. https://doi.org/10.1016/j.marpolbul

Zitko V (1975) Toxicity and pollution potential of thallium. Sci Total Environ 4:185-192. https://doi.org/10.1016/00489697(75)90039-X

Zýka V (1972) Thallium in plants from Alšar. Sbornik Geologických Věd. Technologie a geochemie 10:91-95

Publisher's note Springer Nature remains neutral with regard to jurisdictional claims in published maps and institutional affiliations. 